Pacific Northwest

National Laboratory

Operated by Battelle for the

U.S. Department of Energy

\title{
Analysis of Potential Benefits and Costs of Adopting a Commercial Building Energy Standard in South Dakota
}

D.B. Belzer

K.A. Cort

D.W. Winiarski

E.E. Richman

March 2005

Completed for the Building Standards and Guidelines Program, U.S. Department of Energy under Contract DE-AC06-76RLO 1830 


\section{DISCLAIMER}

This report was prepared as an account of work sponsored by an agency of the United States Government. Neither the United States Government nor any agency thereof, nor Battelle Memorial Institute, nor any of their employees, makes any warranty, express or implied, or assumes any legal liability or responsibility for the accuracy, completeness, or usefulness of any information, apparatus, product, or process disclosed, or represents that its use would not infringe privately owned rights. Reference herein to any specific commercial product, process, or service by trade name, trademark, manufacturer, or otherwise does not necessarily constitute or imply its endorsement, recommendation, or favoring by the United States Government or any agency thereof, or Battelle Memorial Institute. The views and opinions of authors expressed herein do not necessarily state or reflect those of the United States Government or any agency thereof.

\section{PACIFIC NORTHWEST NATIONAL LABORATORY operated by \\ BATTELLE for the \\ UNITED STATES DEPARTMENT OF ENERGY under Contract DE-AC06-76RL01830}

Printed in the United States of America

$$
\begin{aligned}
& \text { Available to DOE and DOE contractors from the } \\
& \text { Office of Scientific and Technical Information, } \\
& \text { P.O. Box 62, Oak Ridge, TN 37831-0062; } \\
& \text { ph: (865) 576-8401 } \\
& \text { fax: (865) 576-5728 } \\
& \text { email: reports@adonis.osti.gov }
\end{aligned}
$$

\footnotetext{
Available to the püblic from the National Technical Information Service, U.S. Department of Commerce, 5285 Port Royal Rd., Springfield, VA 22161 ph: (800) 553-6847 fax: (703) 605-6900 email: orders@ntis.fedworld.gov online ordering: http://www.ntis.gov/ordering.htm
} 
PNNL- 15101

\title{
Analysis of Potential Benefits and Costs of Adopting a Commercial Building Energy Standard in South Dakota
}

\author{
D.B. Belzer \\ K.A. Cort \\ D.W. Winiarski \\ E.E. Richman
}

March 2005

Completed for the Building Standards and Guidelines Program, U.S. Department of Energy

Completed by Pacific Northwest National Laboratory, Operated for the U.S. Department of Energy by Battelle 
|

|

|

|

1

)

1 


\section{Executive Summary}

The state of South Dakota is considering adopting a commercial building energy standard. This report evaluates the potential costs and benefits to South Dakota residents from requiring compliance with the most recent edition of the ANSI/ASHRAE/IESNA 90.1 -2001 Energy Standard for Buildings except Low-Rise Residential Buildings (hereafter referred to 90.1-2001 or ASHRAE 90.1-2001). These standards were developed in an effort to set minimum requirements for the energy efficient design and construction of new commercial buildings. The quantitative benefits and costs of adopting a commercial building energy code are modeled by comparing the characteristics of assumed current building practices with the most recent edition of the ASHRAE Standard, 90.1-2001. Both qualitative and quantitative benefits and costs are assessed in this analysis. Energy and economic impacts are estimated using results from a detailed building energy simulation tool (Building Loads Analysis and System Thermodynamics [BLAST] model) combined with a Life-Cycle Cost (LCC) approach to assess corresponding economic costs and benefits.

The state of South Dakota currently has no state-wide mandatory or recommended minimum commercial building energy code. Even with state adoption, it is expected that local jurisdictions would need to formally adopt this standard as a building code in order to make it mandatory for commercial builders. Because South Dakota does not have a man datory statewide energy code, this study uses two separate baseline building efficiency levels to assess the impacts, generally described as: (1) Low-efficiency Buil dings and (2) High-efficiency Buildings. It is assumed that the "Low-efficiency" buildings would tend to be smaller commercial buildings that do not employ professional arch itectural and engineering firms to design and construct the buildings. The "Highefficiency" buildings are considered "well-engineered" larger buildings that meet or exceed many of the requirements of Standard 90.1-2001 and employ architectural and engineering firms as part of the design and construction process.

The energy simulation and economic results of the building prototypes selected for this study suggest that adopting a standard equivalent to ASHRAE 90.1-2001 as the commercial building energy code in South Dakota would have little impact on the manner in which High-Efficiency buildings are currently built, as these buildings appear to al ready be meeting or exceeding most of the minimum requirements of ASHRAE 90.1-2001. Adopting ASHRAE 90.1-2001 as the minimum standard would have an impact, however, for Low-Efficiency buildings, which may tend to use lower levels of insulation, less efficient windows, and lighting fixtures with higher electricity consumption. For the Low-Efficiency buildings, ASHRAE 90.1-2001 could potentially provide positive net benefits relative to the current building designs and characteristics. For a few of the Low-Efficiency building types, there are no significant net economic benefits to complying with the 90.1-2001 envelope requirements; however, the ASHRAE 90.1-2001 lighting requirements appear to provide significant net economic benefits and energy savings to the building owner. In all cases for Low-Efficiency buildings, the combined envelope and lighting LCC savings of adopting the respective 90.1-2001 requ irements is positive relative to the base cases. 



\section{Contents}

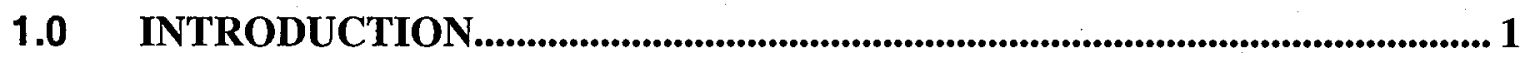

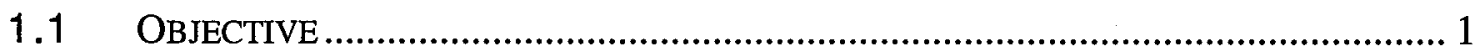

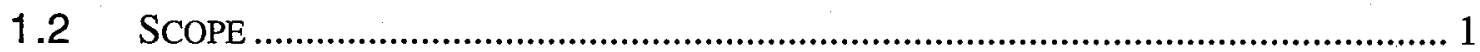

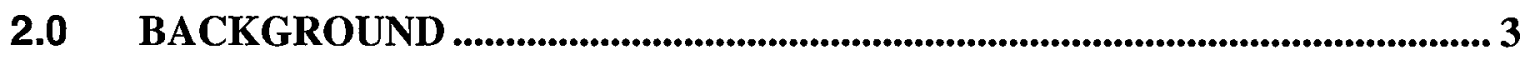

2.1 SUMMARY OF DIFFERENCES BETWEEN STANDARDS ........................................ 3

2.1.1 Building Envelope Standard Changes between 90.1-1989 and 90.1-2001 4

2.1.2 Lighting Standard Changes .................................................................... 5

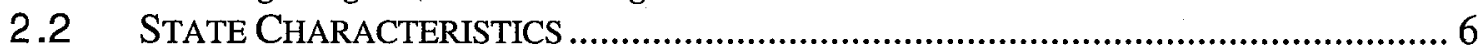

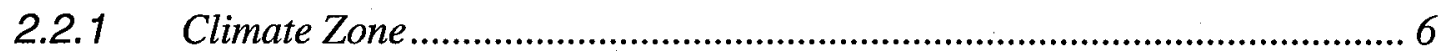

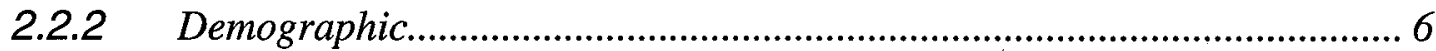

2.2.3 Commercial Construction Characteristics ............................................... 7

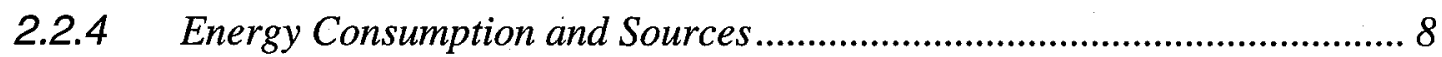

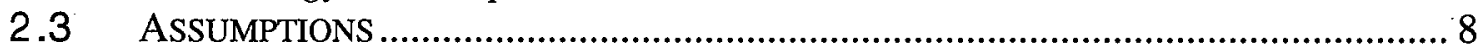

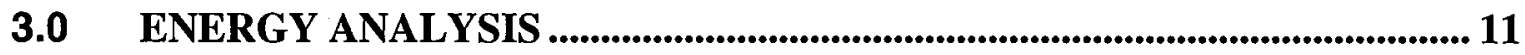

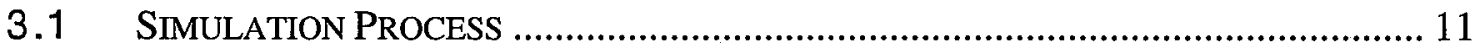

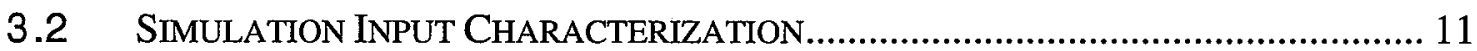

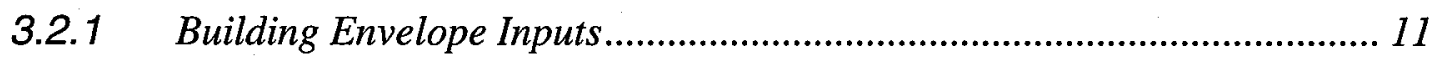

3.2.2 Lighting Inputs ............................................................................... 12

3.2.3 Mechanical Inputs........................................................................ 12

$4.0 \quad$ ECONOMIC ANALYSIS ............................................................................... 13

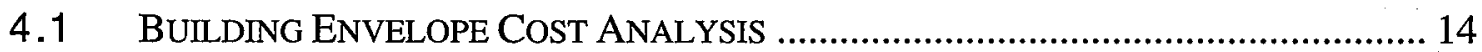

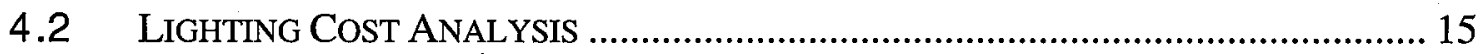

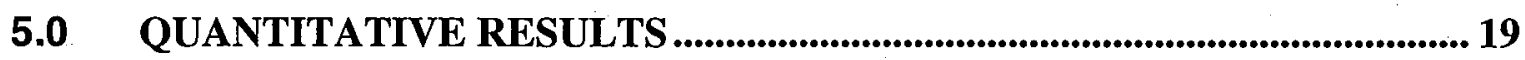

5.1 THE LOW-EFFICIENCY BUILDINGS BASE CASE ................................................ 19

5.1.1 Office Buildings ................................................................................ 19

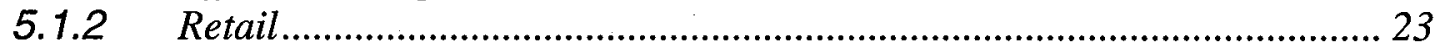

5.2 THE HIGH-EFFICIENCY BUILDINGS BASE CASE ............................................. 25

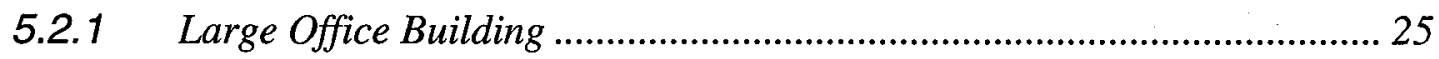

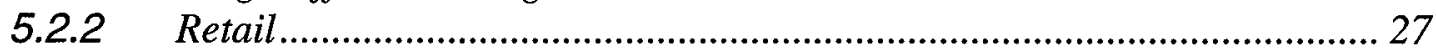

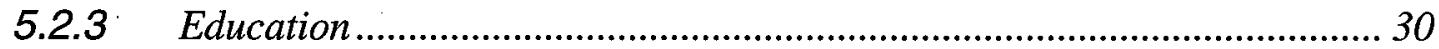

5.3 OTHER FACTORS IMPACTING BENEFITS AND COSTS ....................................... 30

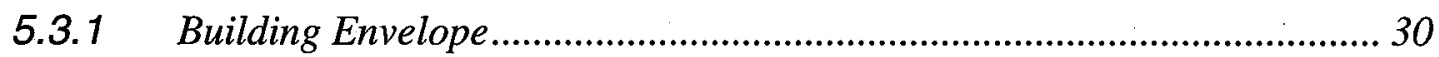

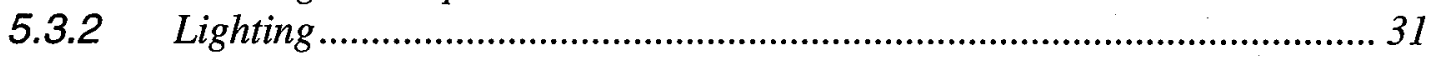

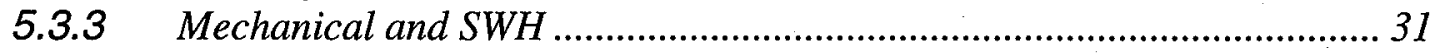

5.3.4 Scope of Standard ..................................................................................... 32

6.0 QUALITATIVE CONSIDERATIONS............................................................... 33

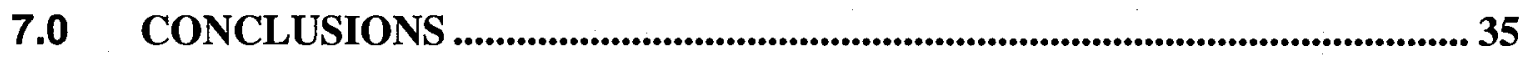

8.0 REFERENCES.................................................................................................................. 37 



\section{Acronyms and Abbreviations}

\begin{tabular}{|c|c|}
\hline $\mathrm{ACP}$ & Alternate Component Packages \\
\hline AIRR & Adjusted internal rate of return \\
\hline ASHRAE & American Society of Heating, Refrigerating and Air-Conditioning Engineers \\
\hline BLAST & Building Loads Analysis and System Thermodynamics \\
\hline BLCC & Building Life-Cycle Cost \\
\hline CBECS & Commercial Buildings Energy Consumption Survey \\
\hline CDD & Cooling Degree-Days \\
\hline CFL & Compact Fluorescent Light \\
\hline DOE & U.S. Department of Energy \\
\hline EIA & Energy Information Administration \\
\hline EPCA & Energy Policy and Conservation Act \\
\hline EUIs & Energy Use Intensities \\
\hline FEMP & Federal Energy Management Program \\
\hline HDD & Heating Degree-Days \\
\hline HID & High Intensity Discharge \\
\hline $\mathrm{HV} A \mathrm{AC}$ & Heating, Ventilation, and Air-Conditioning \\
\hline IES & Illuminating Engineering Society \\
\hline $\mathrm{LCC}$ & Life-Cycle Cost \\
\hline LPD & Lighting Power Densities \\
\hline NEMS & National Energy Modeling System \\
\hline NIST & National Institute of Standards and Technology \\
\hline OMB & Office of Management and Budget \\
\hline PNNL & Pacific Northwest National Laboratory \\
\hline $\mathrm{SC}$ & Shading Coefficient \\
\hline SIR & Savings-to-Investment Ratio \\
\hline SWH & Service Water Heating \\
\hline TMY & Typical Metrological Year \\
\hline TSD & Technical Support Document \\
\hline
\end{tabular}

(Glossary of selected terms found in Appendix A) 
)

)

|

1

1
1

$j$

1
$j$
1
$j$ 


\subsection{Introduction}

\subsection{Objective}

The state of South Dakota is considering adopting the most recent version of the ASHRAE Standard 90.1-2001, as its commercial building energy code. The potential benefits and costs of updating the code are considered in this report in an effort to evaluate whether or not these standards represent an appropriate efficiency level for the state.

This report is written in response to a request for technical assistance from representatives of South Dakota's Energy Management Office in the state Bureau of Administration. The request specified the need for an objective analysis that included the impacts of code adoption on predominant commercial building types in South Dakota.

\subsection{Scope}

This study focuses on three commercial building types: office, retail, and education. These building types are the most common commercial buildings and make up over $60 \%$ of the total value of new commercial construction in South Dakota (Census 2000b). Within these building types, the impacts of the building envelope and lighting requ irements are assessed, while mechanical requirements are excluded because of expected changes in equipment efficiencies due to federal manufacturing standards as referenced under the Energy Policy and Conservation Act (EPCA) as amended by the 1992 Energy Policy Act (EPAct).

Under this legislation, the energy efficiency of most of the heating, ventilation, airconditioning (HVAC) and service water heating (SWH) equipment regulated under IECC and ASHRAE 90.1 Building Cases also regulated by federal manufacturing standards, which by law will soon be updated to levels at least as stringent as those in ASHRAE 90.1-2001. Hence, the savings from these equipment requirements will generally occur regardless of the adoption of a building standard in South Dakota. Efficiency improvements in equipment that are not covered under EPCA are discussed in Section 5.4 along with other requirements in the HVAC and SWH section of the standard. The potential quantitative impact of the equipment standards has been evaluated in detail in the report, Screening Analysis for EPACT-Covered Commercial HVAC and Water Heating Equipment.

While several of its neighboring states have adopted ASHRAE Standard 90.1-1989, South Dakota has never adopted a formal statewide energy code for commercial buildings. Moreover, because there are few local jurisdictions who have reportedly adopted a standard, it is unclear what level of energy efficiency components are being emp loyed in commercial buildings currently built in South Dakota. In order to develop an appropriate baseline of current building practice, information was extracted from a database of new commercial construction characteristics recently developed by PNNL 
(NC3 ${ }^{1}$ database). The characterization of typical construction practices developed from this database was reviewed by staff at the South Dakota State University. This characterization was also informed by experience in preparing a similar study for North Dakota (Cort et. al, 2004). Based on the data gathered, this study develops two separate baseline building efficiency levels, generally described as: (1) Low-Efficiency Buildings and (2) High-Efficiency Buildings. It is assumed that the Low-Efficiency buildings would tend to be smaller commercial buildings and which professional architectural and engineering firms were not employed to design and construct the buildings. This is not meant to suggest that all small commercial buildings are built at a lower efficiency level than larger buildings and larger building prototypes are also included with LowEfficiency characteristics in Appendix B. The High-Efficiency buildings are considered "well-engineered" buildings that meet or exceed the current recommended energy standard. These buildings are assumed to be larger and, as part of the design and construction process, architectural and engineering firms were engaged. An assortment of building types that meet the High-Efficiency criteria are found in Appendix C.

For this analysis, a study period of forty years was chosen to capture changes in building energy consumption from required energy-related designs and materials that occur over the life of the building. Specific simulation and Life Cycle Cost (LCC) assumptions are discussed in the respective sections of this report.

This report includes a summary of background information regarding various building code requirements, state-specific information, and a description of the assumptions required to complete the quantitative analysis. The report includes sections that describe the building simulation process as well as the economic model and the assumptions used to calculate life-cycle cost savings for each building type. Detailed quantitative results are included in the appendix and discussed in Sections 5.

\footnotetext{
${ }^{1}$ NC3 is a database developed by Pacific Northwest National Laboratory based on building characteristics taken from McGraw Hill/F.W. Dodge commercial building plans submitted for bidding. All data is current (submitted in the past 5 years) and the database includes over 160 buildings.
} 


\subsection{Background}

Energy codes set minimum standards for design and construction of buildings. These codes eliminate building design practices that lead to unnecessarily high building energy use and associated costs. Energy cost savings resulting from energy code compliance directly benefit building owners and occupants over the life cycle of the building. An energy code, however, may impose higher initial costs on the building owner, as frequently the incentive is to use equipment and materials that have lower first costs and lower efficiencies. The energy savings also reduce the need for new generating and transmission capacity, and detrimental environmental effects associated with energy production, distribution, and use.

South Dakota has never had a statewide mandatory or voluntary commercial energy code. Nevertheless, it is expected the elements of the ASHRAE-based commercial codes have influence even in states without such codes. In terms of the building structure, builders and architects who work in neighboring states would be expected to be influenced by the codes in adopted in those states. Iowa and Montana adopted ASHRAE/IES Standard 90.1-1989 in the mid-1990s. In 1995 in North Dakota ASHRAE 90.1-1989 was adopted as a statewide minimum standard for state-funded commercial buildings and a voluntary standard for jurisdictions that chose to adopt an energy code.

Given the likely indirect influence that the ASHRAE 90.1-1989 code may have on building practices in South Dakota, it seems reasonable to compare some of key differences between the 1989 ASHRAE code and more recent updates. Since the publication of ASHRAE 90.1-1989 in late 1989, there have been two updates: ASHRAE Standard 90.1-1999 and ASHRAE Standard 90.1-2001. For South Dakota, these updates have very similar requirements. However, the 2001 version of the standard clarifies a number of ambiguities in the 1999 standard and is generally recognized as more amenable to enforce. Accordingly, the approach of this analysis, for the most part, is to compare the impacts of moving from the characteristics that describe a Low-Efficiency Building to requirements that would meet 90.1-2001. The analysis also looks at certain building types that are considered High-Efficiency Buildings and compares the energy use and life-cycle costs of such buildings under assumed sets of characteristics. By assumption, these High-Efficiency buildings are characterized as already meeting or exceeding the energy efficiency criteria in 90.1-1989. All baseline characteristics are described in Section 2.2. It is assumed that the incremental impact between these various building levels adequately captures the range of impacts likely to occur in South Dakota from adopting either ASHRAE 90.1-2001 or ASHRAE 90.1-1999.

\subsection{Summary of Differences between Standards}

Although the quantitative analysis does not directly compare the requirements of 90.11989 and 90.1-2001, 90.1-1989 appears to be the basis of many of the energy-related building components that make up the High-Efficiency building characterizations included in this study, thus, it is useful to observe the differences and similarities between ASHRAE 90.1-1989 and 90.1-2001. 


\subsubsection{Building Envelope Standard Changes between 90.1-1989 and 90.1-2001}

Building envelope requirements apply to those components (e.g., walls, windows, roofs, and floors) that are separate conditioned (i.e., heated and cooled) spaces from unconditioned spaces or the outdoors. The requirements vary by climate. The portion of ASHRAE 90.1-2001 that addresses building envelope requirements includes prescriptive as well as mandatory and trade-off options. Window and door requirements specify Ufactors and fenestration solar heat gain coefficients (the 90.1-1989 edition actually specified shading coefficient requirements). ASHRAE 90.1-2001 has added air leakage requirements that apply to South Dakota climates for the sealing of openings and joints in the building envelope (including windows and doors, loading docks, and vestibules). The prescriptive path of 90.1-2001 also includes methods for calculating U-factors, C-factors, and F-factors for pre-assembled envelope sections. A performance trade-off option in both standards allows designers to use any combination of building envelope materials that meet both the mandatory requirements and a minimum envelope performance factor.

The general difference between ASHRAE 90.1-1989 and ASHRAE 90.1-2001 is the approach used to justify the minimum envelope requirements. ASHRAE 90.1-1989 envelope requirements were primarily based on professional judgment regarding building type, characteristics, and climate. ASHRAE 90.1-2001 requirements put more emphasis on an economic justification of energy efficiency that considers life-cycle costs as a means of balancing energy savings with the increased first cost of materials and equipment.

One other significant difference between the ASHRAE 90.1-1989 and 90.1-2001 is that ASHRAE 90.1-1989 focused on setting a single performance requirement for "all roofs" or "all walls" or "all floors" while 90.1-2001 looks at differences in types of roofs, walls, and floors. The outcome of this is that ASHRAE 90.1-1989 has a requirement for "all roofs" (or walls or floors) that is based on the performance of the best performing construction while 90.1-2001 has requirements specific to each type of construction (e.g., performance requirements of mass walls are different than metal-framed walls). The end result is that ASHRAE 90.1-1989 often requires higher insulation levels for buildings that are typically constructed with less insulation than 90.1-2001 (e.g., requirements for metal-frame buildings tend to be more stringent in ASHRAE 90.1-1989 than in 90.12001). In addition, ASHRAE 90.1-1989 requirements are characterized based on overall wall thermal performance (window plus opaque wall area) while 90.1-2001 treats windows and opaque walls separately.

An additional distinction between ASHRAE 90.1-1989 and 90.1-2001 is that ASHRAE 90.1-1989 is based on a series of continuous efficiency (e.g., wall U-value) curves, leading to continuously changing requirements by climate. ASHRAE 90.1-2001 envelope requirements were based on real building assemblies and hence have U-values that reflect real and typical assemblies and construction components. Thus, the1989 standard may have wall insulation requirements of R-5.4, R-7.2, R-8.6, R 9, R-10, and R11.3 for different locations where 90.1-2001 would have fewer distinct requirements (either R-7 or R-11 or R-13). The resulting impact of the ASHRAE 90.1-1989 requirements is that one would typically need to exceed the prescriptive requirements in 
order to find a commercially available product ${ }^{2}$. The design of 90.1-2001 requirements are based only on commonly available R-value insulation and the life cycle fuel cost savings are based on the incremental cost of going to the next level of construction.

\subsubsection{Lighting Standard Changes}

The ASHRAE 90.1-1989 section on lighting includes both mandatory provisions and a prescriptive path to determine compliance. The 1989 mandatory requirements cover minimum lighting controls and their accessibility and include restrictions on single-lamp ballasts when more efficient multiple-lamp ballasts can be used. The ASHRAE 90.11989 Standard includes efficiency requirements for ballasts, which have been absorbed into federal manufacturing standards under EPCA. Automatic controls are not required in the 1989 standard but credits allowing higher lighting power densities (LPDs) are available if occupancy, lumen maintenance, and/or daylight sensors are installed.

Whole building lighting power densities are considered the most reasonable and practical method of comparing lighting requirements between codes. However, the ASHRAE 90.1-1989 standard provides direct lighting densities for only a few building categories and sizes. Therefore, LPDs for whole buildings used in this comparison were calculated on a space-by-space basis to provide similar representation in ASHRAE 90.1-1989. This provides the most directly comparable basis between the two standards.

The mandatory provisions in 90.1-2001 focus on lighting controls and efficient use of lighting ballasts. The primary requirement is an automatic lighting control, which could be met by a programmable whole building lighting shutoff control, occupancy sensors, or similar automatic lighting shutoff control system. Other control requirements define limits for area control of lighting, use of photosensor or timeclock controls for exterior lights, and additional controls required for specific lighting tasks. The use of less efficient single-lamp fluorescent ballasts is reduced through tandem wiring requirements. The mandatory section also defines calculation of fixture wattage and sets power and efficiency limits for exit signs and exterior lighting.

The 90.1-2001 prescriptive path includes interior and exterior lighting power allowances, where the interior lighting power allowances may be determined by using either the total building area or the space-by-space (e.g., office, hallway) method. Interior lighting power requirements allow for design differences and special lighting needs by providing power allowances for decorative, display, accent lighting, merchandise highlighting, and computer screen glare reduction in specified spaces. Lighting excluded from the code is identified for specific tasks or applications such as safety lighting and lighting within living units. Exterior lighting, used at building entrances and exits and for building highlighting, has specified power limits while other exterior grounds lighting is limited to efficiency requirements for the light source.

Table 1 shows a comparison of the requirements in 1989 and 2001 editions for some selected lighting power density allowances using the whole building and space-by-space methods.

\footnotetext{
${ }^{2}$ For example, $90.1-1989$ could require an R-10.6 wall, where the only thing that would meet this requirement in the market would be an R-11 wall.
} 
Table 1. Comparison of Lighting Power Densities - Standards 90.1-1989 and 90.1-2001

\begin{tabular}{|c|c|c|c|c|c|}
\hline \multicolumn{3}{|c|}{$\begin{array}{l}\text { Whole Building Method } \\
\left.\text { Lighting Power Densities (W/ } / \mathrm{ft}^{2}\right)\end{array}$} & \multicolumn{3}{|c|}{$\begin{array}{l}\text { Space-by-Space Method } \\
\text { Lighting Power Densities }\end{array}$} \\
\hline Building Type & $90: 1-2001$ & $90.1-1989$ & Space Type & $90.1-2001$ & $90.1-1989$ \\
\hline Hospital & 1.6 & NA & Office Enclosed & 1.5 & 1.8 \\
\hline Library & 1.5 & $\mathrm{NA}$ & Office Open & 1.3 & 1.9 \\
\hline Manufacturing & 2.2 & $\mathrm{NA}$ & Conference & 1.5 & 1.8 \\
\hline Museum & 1.6 & NA & Training & 1.6 & 2.0 \\
\hline Office & 1.3 & 1.5 to 1.9 & Lobby & 1.8 & 1.9 \\
\hline Parking Garage & 0.3 & 0.2 to 0.3 & Lounge/Dining & 1.4 & 2.5 \\
\hline Retail & 1.9 & 2.1 to 3.3 & Food Prep & 2.2 & 1.4 \\
\hline School & 1.5 & 1.5 to 2.4 & Corridor & 0.7 & 0.8 \\
\hline & & & Restroom & 1.0 & 0.8 \\
\hline & & & Active Storage & 1.1 & 1.0 \\
\hline
\end{tabular}

\subsection{State Characteristics}

The building simulation and LCC inputs of this study are characterized to fit statespecific characteristics such as climate, building construction trends, and energy source characteristics. The following sections provide some of the key components considered in tailoring the study to the state.

\subsubsection{Climate Zone}

Climate zones are defined by long-term weather conditions, which affect heating and cooling loads in buildings. The zones are based on annual average number of degreedays, which are a measure of how cold/hot a building location is relative to the base temperature ${ }^{3}$. As heating is more relevant than cooling for buildings in South Dakota, the variation in heating degree-days (HDD) may suggest distinct climate zones. The range of HDD across the state is illustrated by Rapid City with 7,301 HDD as compared to Brookings with over $8,600 \mathrm{HDD}$. However, this difference was not deemed sufficient by ASHRAE to differentiate different climate zones within South Dakota. As a result, the insulation and window requirements in ASHRAE Standard 90.1-2001 are the same across all locations in South Dakota.

\subsubsection{Demographic}

South Dakota has a population of approximately 760,000 people. Sioux Falls is the largest city, with approximately 125,000 people. From 1990 to 2000, South Dakota's population grew by $8.5 \%$ (Census $2000 \mathrm{a}$ ). In 2002 the value of new nonresidential construction in South Dakota was approximately $\$ 450$ million. Office, retail, and

\footnotetext{
${ }^{3}$ The daily heating degree days (HDD) is the numerical difference between a day's average temperature and a reference temperature, commonly 65 degrees Fahrenheit (HDD is defined as zero if the day's average temperature is greater than $65^{\circ} \mathrm{F}$. The annual HDD is the sum of the daily HDD for the year. The daily cooling degree days (CDD) is the numerical difference between a day's average temperature and a reference temperature (e.g., for a 50 degree Fahrenheit reference temperature, $\mathrm{CDD}$ is defined as zero if the day's average temperature less than $50^{\circ} \mathrm{F}$ ). The annual $\mathrm{CDD}$ is the sum of the daily CDD for the year.
} 
education buildings contributed to over half the total value of new construction in that year (Census 2000b).

\subsubsection{Commercial Construction Characteristics}

In order to develop an appropriate baseline of current building practice, data was gathered from the NC3 database, and information from this database was reviewed by the staff conducting a DOE SEP funded energy code study for the State of South Dakota at South Dakota State University in conjunction with one experienced building engineering professional in South Dakota ${ }^{4}$.

The NC3 database contains very specific and detailed data on the various energy related components of new building construction. This includes details on space heating, cooling, water heating, lighting, insulation, controls, structure, and materials as they are currently applied in new commercial building construction. Data is compiled from building plans taken from buildings that are in the final bid process where plans and specifications are complete and construction is anticipated to start within a year or two. The specific source of these sets of building plans and specs is the F.W. Dodge Plans division of McGraw-Hill. Although limited in number (currently contains 162 buildings across the U.S.), this data provides at least a partial representation of current building practices. This database was queried for all commercial buildings in relatively cooler northern climates, similar to South Dakota that had not recently adopted mandatory commercial building energy codes.

Information regarding wall, floor, and roof insulation levels was extracted from the database, as well as average window u-values and solar heat gain coefficients. In addition, general construction characteristics were developed that provided information regarding common building practices such as types of roofs (e.g., built-up flat roofs vers us metal roof decking), walls (e.g., masonry versus steel framing), and window-towall ratios. Information on lighting levels (watts/ $\mathrm{ft}^{2}$ ) was also extracted by building type. Although changes in HVAC equipment are not covered in this report, information was gathered on the type of HVAC equipment and systems that are commonly installed in northern climates.

In each category, the results of the database query indicated that most building types appeared to fall into one narrow range of insulation; however outliers were found in each cate gory. For each building component, questions were asked of several building engineering consultants from South Dakota. These consultants provided expert opinion regarding the level of insulation and types of components that are believed to represent current building practices in South Dakota.

The results of the database query and the consultant's expert opinion were combined to develop two separate base cases: (1) Low-Efficiency Buildings and (2) High-Efficiency Buildings. Low-Efficiency buildings are assumed to include smaller office buildings and retail strip malls for which professional architectural and engineering firms were not used to design and construct the buildings. The High-Efficiency buildings include larger

\footnotetext{
${ }^{4}$ M.P. Twedt and D.W. Hengeveld, Mechanical Engineering Department, South Dakota State University.
} 
office buildings, large retail buildings and school buildings, where it is assumed that architectural and engineering firms were employed in the design and construction process of these buildings.

\subsubsection{Energy Consumption and Sources}

South Dakota consumes approximately 250 trillion Btu of energy each year and approximately $20 \%$ of this energy is consumed by the commercial buildings sector. Natural gas is the primary energy source for commercial building heating in South Dakota. Hydroelectric dams generate the majority of electricity in South Dakota, with natural gas supplying most of the non-hydro based production (EIA 2003c).

\subsection{Assumptions}

South Dakota is one of the nation's coldest states, with heating degree days over 8,000 for many of the towns and cities. The climate of Sioux Falls was used to simulate energy use in buildings, as Sioux Falls is South Dakota's largest city and has a climate reasonably representative of many of the state's other jurisdictions. Sioux Falls averages around 7,800 HDD and 2,700 CDD. The weather data actually used in this simulation analysis is taken from the Typical Meteorological Year (TMY2) weather data set.

This study focuses on three different commercial building types: office, retail, and education. Five building design prototypes are characterized and assessed. All buildings are characterized as rectangular buildings; however, they vary in size and window-to-wall ratios. A relatively small (1-story, $10,000 \mathrm{ft}^{2}$ ) office building and a larger office building ( 3 floors, $60,000 \mathrm{ft}^{2}$ ) are simulated and the larger-sized office is simulated with two separate window-to-wall ratios. Also, a 24,000 square foot, single-story ("big box") retail building and two education buildings are characterized in this evaluation. $\mathrm{A}$ general description of all five buildings analyzed is shown in Table 2.

The insulation requirements in ASHRAE Standard 90.1 differ by various types of wall and roof assemblies. This study selects the predominant assembly types for conducting the simulation analysis. Roofs may be 1) flat with insulation above the deck, 2) as part of a metal building, or 3) sloped with attics similar to typical residential construction. This study considers only flat roofs with insulation above the deck. For wall assemblies, the major types of construction include: 1) mass (concrete) walls, 2) steel frame, and 3) wood frame. For this study, steel frame walls are assumed. While these specific assemblies were chosen for the simulation modeling, information from the other building assembly types were based on data from the NC3 database to formulate the specific insulation assumptions. 
Table 2. Study Building Set

\begin{tabular}{||l|c|c|c|c||}
\hline Building Type & $\begin{array}{c}\text { Window-to-Wall } \\
\text { Ratio }\end{array}$ & $\begin{array}{c}\text { Square } \\
\text { Footage }\end{array}$ & $\begin{array}{c}\text { Number of } \\
\text { Floors }\end{array}$ & Aspect Ratio $^{1}$ \\
\hline Small Office-1 & $18 \%$ & 10,000 & 1 & 2.25 \\
\hline Large Office-3 & $18 \%$ & 60,000 & 3 & 2.25 \\
\hline Large Office-4 & $38 \%$ & 60,000 & 3 & 2.25 \\
\hline Retail & $7 \%$ & 24,000 & 1 & 2.5 \\
\hline $\begin{array}{l}\text { Education } \\
\text { (Elementary } \\
\text { Style Design) }\end{array}$ & $18 \%$ & 50,000 & 1 & 6 \\
\hline${ }^{1}$ The aspect ratio is the building length divided by the building width. \\
\hline
\end{tabular}

It is assumed that the Low-Efficiency base building type is built with wall insulation with U-factors of 0.11 . This value is equivalent to a $5 \frac{1 / 2}{2}$ inch metal frame wall with R-19 insulation in the wall cavity-several buildings in the NC3 sample used this type of insulation. This value does not meet the ASHRAE 90.1-2001 standard of 0.089. For roof insulation, it is assumed that the Low Efficiency building falls about $15 \%$ short of meeting the 90.1-2001 Standard. (While flat roofs are assumed in the simulation here, several buildings with attics in the NC3 database had insulation levels that were less than the R-38 level prescribed by the standard). The windows for the Low-Efficiency buildings are assumed to be equivalent to a metal-framed, double-paned clear window without a low-e coating.

For the High-Efficiency building types, the roofs are assumed to be equivalent to the requirement in ASHRAE 90.1-2001; i.e. R-15 continuous insulation for a built-up flat roof. The High-Efficiency wall characteristics are based on NC3 data that suggests $80 \%$ of the wood frame walls exceed the ASHRAE 90.1 requirements. To reflect this data, the High-Efficiency walls were simulated with U-factors that exceeded standard by about $10 \%$ The windows in the High-Efficiency building types, excluding retail, are assumed to be equivalent to a metal-framed, double-paned window with some form of a low-e coating and tinting. (Tinting was observed for $15 \%$ of the buildings in the NC3 database, yielding a much lower Shading Coefficient [or Solar Heat Gain Coefficient] than clear glass). For retail buildings, the windows were assumed to be also Low-E, but clear.

It is assumed that all these representative buildings are heated with a gas furnace and cooled with an electric air conditioner. The economic study period is set to be 40 years to adequately capture the changes in energy expenditures and replacement of key components over the (economic) life of the building. Costs and benefits are expressed in 2004 dollars, unless otherwise specified. 



\subsection{Energy Analysis}

Annual energy use simulations were made using the BLAST building engineering model, developed by the Building Systems Laboratory of the University of Illinois. BLAST performs hourly energy simulations of buildings, air-handling systems, and central plant equipment.

\subsection{Simulation Process}

The BLAST simulations were based on a 3-story prototype building with fifteen thermal zones. Each simulation utilized a specific combination of either "Low-Efficiency," or "High-Efficiency" characteristics and then was compared against a simulation using 90.1-2001 standard levels for lighting, equipment, and building envelope design. Each simulation provides annual Energy Use Intensity $\left(\mathrm{Btu} / \mathrm{ft}^{2}\right)$ for gas and electricity in each of the thermal zones. The Energy Use Intensities (EUIs) for each of the representative building types presented in Section 2.3 and simulated in the Sioux Falls climate were scaled to appropriately reflect variations in assumed building size and shapes.

\subsection{Simulation Input Characterization}

\subsubsection{Building Envelope Inputs}

The building envelope characteristics examined in the analysis were: U-factors for opaque walls, roofs, and fenestration (windows); and Solar Heat Gain Coefficient requirements. These characteristics were determined for each of the building types and requirement changes. Table 3 presents the assumed baseline characteristics for LowEfficiency and High-Efficiency commercial buildings, as discussed in Section 1.2. The last column in the table shows the requirements for a metal-framed, built-up flat roof commercial building under ASHRAE Standard 90.1 for South Dakota. The simulated Ufactors are also included for each building type in the tables in Appendixes C and D.

Slab insulation requirements (for buildings with unheated slab foundations) were part of the ASHRAE 90.1-1989 Standard, but were dropped in the 1999 and 2001 versions of the ASHRAE Standard. Nevertheless the NC3 data and anecdotal evidence suggest that slabs are typically insulated in most northern states. For the study, we assumed that slabs would continue to be insulated even after the adoption of an ASHRAE 90.1-based building code. Accordingly, the simulation models in all cases assumed that slabs were insulated on their perimeter, using R-8 insulation extending to a 24 -inch depth.

Table 3. Envelope Characteristics of Low-Efficiency and High-Efficiency Baselines

\begin{tabular}{|l|c|c|c|}
\hline & $\begin{array}{l}\text { Low-Efficiency } \\
\text { Base }\end{array}$ & $\begin{array}{l}\text { High-Efficiency } \\
\text { Base }\end{array}$ & $\mathbf{9 0 . 1 - 2 0 0 1}$ \\
\hline Wall U-Factor & .11 & .076 & 0.089 \\
\hline Roof U-Factor & .078 & .063 & 0.063 \\
\hline Window U-Factor & .72 & .60 & 0.57 \\
\hline Shading & .84 & .79 (retail) & 0.57 (retail) \\
Coefficient & & 0.53 (other) & 0.45 (other) \\
\hline
\end{tabular}




\subsubsection{Lighting Inputs}

The lighting power density requirements were developed from the whole building lighting requirements for both ASHRAE 90.1-1989, ASHRAE 90.1-2001 and based on current practice data gathered from the NC3 database for comparable building types. The 90.1-2001 Standard provides single value whole building lighting power density values for fourteen different building types.

The 90.1-2001 lighting requirements provide single value, whole building, LPD requirements for office, retail, and school buildings, and these requirements were used in the simulations. Table 4 shows a comparison of the Whole Building lighting assumptions made for the Low-Efficiency base case and the High-Efficiency base case as well as for the requirements under both ASHRAE 90.1-1989 and 90.1-2001.

Table 4. Lighting Power Density (Watts/ $\mathrm{ft}^{2}$ )

\begin{tabular}{|l|c|c|c|c|}
\hline Building Type & $\begin{array}{c}\text { Low- } \\
\text { Efficiency } \\
\text { Base }\end{array}$ & $\begin{array}{c}\text { High- } \\
\text { Efficiency } \\
\text { Base }\end{array}$ & $\mathbf{9 0 . 1 - 1 9 8 9}$ & $\mathbf{9 0 . 1 - 2 0 0 1}$ \\
\hline Education & 1.79 & 1.5 & 1.79 & 1.50 \\
Offices & 1.63 & 1.3 & 1.63 & 1.30 \\
Retail & 2.36 & 1.9 & 2.36 & 1.90 \\
\hline
\end{tabular}

\subsubsection{Mechanical Inputs}

Although mechanical equipment is not included in the scope of this economic analysis, some energy simulation results for the average national impact of this requirement are available. DOE's overall comparison of the improvements in mechanical system efficiencies between ASHRAE 90.1-1989 and 90.1-2001, nationwide, shows a 2.2\% efficiency improvement in whole building Electric EUI and 3\% efficiency improvement in Gas EUI'.

\section{Heating and Cooling}

There is relatively little improvement in heating equipment efficiency requirements in ASHRAE 90.1-2001 compared to minimum manufacturing requirements for equipment used in single zones systems (typically furnaces). In the case of cooling equipment, the average efficiency of cooling equipment, based on shipped capacity of the different cooling equipment types used in commercial buildings, increased $7.5 \%$.

\section{Service Water Heating}

Service water heating equipment efficiencies increased from $78 \%$ to $80 \%$ for most tanktype gas fired water heaters.

\footnotetext{
${ }^{5}$ The national simulation results for the Department of Energy's Determination regarding whether ASHRAE 90.1-1999 would improve energy efficiency in new commercial buildings are also found on the Building Standards and Guidelines website (http://www.energycodes.gov/implement/determinations_com.stm).
} 


\subsection{Economic Analysis}

The economic benefit and cost analysis of adopting ASHRAE 90.1-2001 utilizes the LCC approach, which compares the monetary savings over a specified time horizon with the associated costs of complying with the code. For this study, the LCC is a general measure of the cost of operating a building over its assumed 40-year lifetime and includes the initial incremental construction cost, replacement of key components, and annual energy expenditures. A key assumption in the valuation of future benefits and costs is the time-value of money or discount rate that reflects the opportunity cost of capital.

Several factors influence the cost and savings from adopting an energy efficiency building code -first costs, replacement costs, maintenance costs, and energy savings. The primary costs associated with code adoption are the incremental costs of required materials and installation that will contribute to reduced annual energy consumption (e.g., higher levels of insulation, more efficient light fixtures) relative to the cost of building materials that would satisfy a less stringent set of requirements. These costs are often referred to as "first costs," as they are incurred when the building is first built. The collection and treatment of first costs for lighting and building envelope materials is discussed in the following sections. In addition to the first costs, many components will need to be replaced during the 40-year period assumed in this study. The sum of the first cost and the replacement cost is referred to as total investment cost. A comparison of ongoing maintenance costs (excluding replacement costs) for various types of equipment and materials is not included in this analysis (i.e., it can be interpreted that maintenance costs are assumed to be the same for the base case and for ASHRAE 90.1-2001.)

The primary ongoing monetary benefit of the code is the energy saved over the life of a building by using relatively more energy-efficient designs, materials, and equipment. The incremental energy savings are valued using forecasted average commercial gas and electricity rates over a specified time horizon. These future values of replacement costs and energy savings are then discounted to a present value. This study uses a constant $7 \%$ (real) discount rate, which is consistent with the value used by U.S. Department of Energy in analyses of residential and commercial equipment efficiency standards ${ }^{6}$.

The current average gas and electricity prices for South Dakota were obtained from the Energy Information Administration (EIA) and are listed in Table 5 (2005). Based on the

\footnotetext{
${ }^{6}$ This particular value is motivated by the recommendation of the Office of Management and Budget (OMB) in Circular A-94, (OMB1992). Circular A-94 indicates that this value corresponds to the approximate marginal pretax rate of return on the average investment in the private sector in recent years. All rates are reported as "real" rates, which refers to the discount rate above any nominal inflation rate.
} 
Annual Energy Outlook 2003 forecasts (EIA 2004b) the average fuel rates are escalated throughout the first 20-years of the study period and are assumed to remain flat the remaining 20 years of the study period.

Table 5. Commercial Average Annual Fuel Rates in South Dakota

\begin{tabular}{|c|c|}
\hline $\begin{array}{c}\text { Average Annual Price of } \\
\text { Natural Gas } \\
(\mathbf{2 0 0 4 )}\end{array}$ & $\begin{array}{c}\text { Average Annual Price of Electricity } \\
\mathbf{( 2 0 0 4 )}\end{array}$ \\
\hline$\$ 8.20 /$ thousand cubic feet $^{7}$ & $\$ .067 / \mathrm{kWh}$ \\
\hline
\end{tabular}

The economic impacts are calculated using a spreadsheet-based LCC model that compares alternative sets of building technologies corresponding to different building standards. The model borrows elements of the Building Life-Cycle Cost Program (BLCC) produced by the National Institute of Standards and Technology (NIST) and DOE Federal Energy Management Program (FEMP) ${ }^{8}$.

\subsection{Building Envelope Cost Analysis}

The costs for various building envelope materials are derived on a square footage basis. Costs for walls, roofs, and floors are dependent on the type of construction (e.g., masonry wall versus frame, or flat built-up roof versus pitched roof with attic) and vary by U-factors. Discrete costs for various assembly types are based on cost estimates gathered during the development of the ASHRAE 90.1-1999 standard by the ASHRAE envelope subcommittee. Costs for windows and glazing materials were gathered and compiled by Charles Eley Associates. Although costs were collected from 1994-1997, all costs are appropriately inflated to 2004 dollars by using price indexes from the Producer Price Index for specific building materials.

The building envelope costs are measured and reported as incremental costs to achieve a certain level of thermal integrity (U-factor). For the roof and opaque walls, the costs are estimated relative to a base wall and roof assembly containing no insulation. The window costs measure the incremental costs of glazing that has a specific U-factor and shading coefficient, as compared to a metal-framed window with a single pane of clear glass.

For all envelope components, the spreadsheet model estimates the incremental costs per square foot for alternative levels of standards. The incremental costs per square foot are multiplied by the appropriate area (roof, walls, and windows) to generate a total incremental building envelope cost. The envelope first costs, therefore, do not reflect the total cost of constructing roofs, walls, and windows.

\footnotetext{
${ }^{7}$ Equivalent to $\$ 7.98 /$ Million Btu

${ }^{8}$ Portions of a spreadsheet version of the BLCC, developed by M.S. Addison and Associates (Tempe, AZ) were adapted for use in the more extensive LCC model used for this study.
} 


\subsection{Lighting Cost Analysis}

There are numerous advantages to integrating flexibility into standards for the purpose of enabling consumers to choose lighting options appropriate for their situations. This flexibility, however, makes evaluating the economic impacts quite challenging because there are alternative ways to comply with the standard. Although a variety of alternatives may result in similar energy use outcomes, each alternative has its own distinct cost implication.

In order to assess the economic impacts of lighting characteristics between the baseline and 90.1-2001, the factors impacting lighting design choices must be considered. Some of the primary lighting design choices affecting application of lighting technology in buildings include the following:

- Luminance Level - this varies based on the needs of the space, including task requirements, occupants, and overall desired atmosphere of the environment and is generally driven by recommendations made by the Illuminating Engineering Society (IES).

- Lighting Technology Type (e.g., incandescent, fluorescent, high intensity discharge (HID), and ballast choices)

- Light Distribution Technology Type (e.g., lenses, louvers, reflective luminaries, and reflective materials).

It is likely that a lighting design change going from a Low-Efficiency base to the more stringent requirements of 90.1-2001 would primarily involve technology changes only. Other potential methods of complying with a new code would include selected lighting level reduction and/or total redesign of the space using advanced lighting techniques. Total redesign of the space, however, is considered to be uncommon in practice and will not be considered in this analysis. The High-Efficiency base case is assumed to already meet the 90.1-2001 lighting requirements.

Each space (office, hallway, sales area, etc.) within each building type in the ASHRAE 90.1-2001 Whole Building Space Data Allocations is based on up to three different lighting types with each type representing a lighting technology and associated fixture ${ }^{9}$. The amount of light specified for each space (determined by IES recommendations and ASHRAE sub-committee input) is further allocated to each of these (up to three) lighting types. Each of these types is also further defined by an efficacy of the technology (lumens per watt) and standard adjustment factors (lumen depreciation, room surface, etc.).

The set of space type allocations listed in the ASHRAE 90.1-2001 Space Type Models provide one method of meeting the lighting power limit requirements of the standard. These models, based on actual designer and experience input, are considered the most accurate and detailed of their kind available for providing efficient and effective lighting.

\footnotetext{
${ }^{9}$ For example, the three lighting types for a typical office conference room include linear fluorescent, wall wash fluorescent, and halogen down lights.
} 
The models also serve as the basis for comparison with other standards or current practice scenarios.

The approach used to evaluate lighting benefits utilizes-lighting costs for systems of lighting, which include the lamp, fixture, and ballast combination. First, the ASHRAE Space Models are applied to the spaces in each building type to determine the lighting system that meets the standard at the lowest cost. The power densities and costs are then developed for each space and lighting system, and aggregated up to the whole building level for the analysis

The assignment of differences in power densities between 90.1-2001 and the base case can be evaluated as either differences in light level or the efficacy of lighting technologies (or both). Some assumptions are made to permit a reasonable assessment of the actual difference in design to meet the two standards and allow a comparison of energy consumption and costs. Because of the vast variance in lighting design, it is impractical to assign too much detail to a scenario; however, many common space types within buildings exhibit some common lighting design attributes. Some examples are included in Table 6.

Table 6. Selected Examples of Building Spaces and Corresponding Common Lighting Designs

\begin{tabular}{|l|l|}
\hline Space Type & Lighting Design Characteristics \\
\hline Typical open office areas & $\begin{array}{l}\text { Evenly spaced fluorescent troffers with little decorative } \\
\text { lighting }\end{array}$ \\
\hline Typical enclosed offices & Fluorescent troffers \\
\hline Hallways/lobbies & Fluorescent troffers and incandescent downlights \\
\hline Large Retail spaces & $\begin{array}{l}\text { Overhead fluorescent troffers and incandescent } \\
\text { display lights }\end{array}$ \\
\hline
\end{tabular}

Since the lighting requirements for the 90.1-2001 standard are well defined through the use of the space type models as described above, the development of capital costs for lighting meeting the base case characteristics is based upon a substitution of less efficient technologies than those used to comply with the 2001 standard. The substitution involves two types of lighting systems:

1) Magnetic ballast-T12 lamps for electronic ballast-T8 lamps

2) Incandescent lamps for compact fluorescent lamps in downlight applications.

As a first step, cost estimates were developed for the linear fluorescent and incandescent/CFL applications for both the 90.1-2001 standard based upon the ASHRAE Models. The less efficient technologies associated with the Low-Efficiency base case levels were then substituted into the same 90.1-2001 models (i.e., assuming the same illumination levels) to determine a corresponding increase in predicted LPD. A ratio was computed between the reduction in cost and the increase in the predicted LPD, going. from the more efficient to the less efficient lighting technologies. This ratio was then applied to the actual difference in the LPD between the two standards to make an estimate of the change in cost. 
Lighting costs are measured in terms of total lighting cost in dollars per square foot for linear fluorescent and incandescent/CFL systems. These costs include the cost of a fixture, ballast, and lamp plus the labor cost to install the assembly. The linear fluo rescent lighting cost estimates are based on data from the Technical Support Doc ument (TSD) for the DOE's rulemaking related to fluorescent lamp ballasts (DOE 1999). For compact fluorescent and incandescent systems, data were developed from the input data used in the commercial module of the National Energy Modeling System (NEMS) and from a PNNL analysis of contractor prices from Grainger Industrial Supply. Although the lighting cost may vary for any particular building due to the type of lighting technology used, the above derivations are representative of the cost differentials. 



\subsection{Quantitative Results}

The changes in energy use between base cases and 90.1-2001 are calculated in terms of EUI by fuel type as developed from simulations of the base cases and the 90.1-2001 standard for each zone of the prototypical building. These zonal results are then scaled to the building type of interest. The zone EUIs by fuel type can thus be converted to site energy, source energy, and energy cost intensities, by building type. Specific building simulation inputs and resulting energy savings for particular building types included in this study are found in Appendixes $B$ and $C^{10}$.

This section presents the estimated energy and economic impacts between two separate base cases and ASHRAE 90.1-2001 building standards for the selected set of buildings. Three separate variations of the 2001 standard are compared with the base case characteristics: 1) Changing only requirements related to the building envelope; 2) Changing only lighting requirements; and 3) Changing both envelope and lighting requirements. This methodology helps to better understand how the energy and economic impacts are linked to various aspects of the standards. The combined lighting and envelope case shows the degree to which interaction between the envelope and lights affect the overall impacts.

\subsection{The Low-Efficiency Buildings Base Case}

As discussed in Section 2.3 and 3.2, two separate base cases are modeled to capture the range of impacts based on current construction practices in the commercial sector of South Dakota. Of the prototypical building types modeled, the "Low-Efficiency" cases are more likely to be characterized by the small office building, with a window-to-wall ratio of $18 \%$ and the retail building. Although the smaller retail building and small office building appeared to be the most likely types of buildings to be built at the LowEfficiency level, additional building types are modeled with Low-Efficiency characteristics and the results are all included in Appendix B. All of the buildings are characterized as having metal frame walls.

\subsubsection{Office Buildings}

Table 7 presents the engineering and cost summary for the small, 10,000 square foot, single-story office building in South Dakota. The top panel of the table shows the key engineering and cost inputs for the building envelope. Based upon a building height of 13 feet, and an aspect ratio of 2.25 (ratio of building length to width), the total wall area of the building is 5,733 square feet. Given the assumed window-to-wall ratio of 0.18 , this translates into 1,013 square feet of windows and 4,619 square feet of opaque wall. In a building with a single floor, the roof area is equal to the floor area. The insulation requirements for the slab are related to the perimeter length. For this building, the

\footnotetext{
${ }^{10}$ The national simulation results for the U.S. Department of Energy's Determination regarding whether ASHRAE 90.1-1999 would improve energy efficiency in new commercial buildings are also found on the Building Energy Codes website (http://www.energycodes.gov/implement/determinations com.stm).
} 
perimeter of the building is 433 feet. Figure 1 provides an illustration of an office building that has these characteristics.

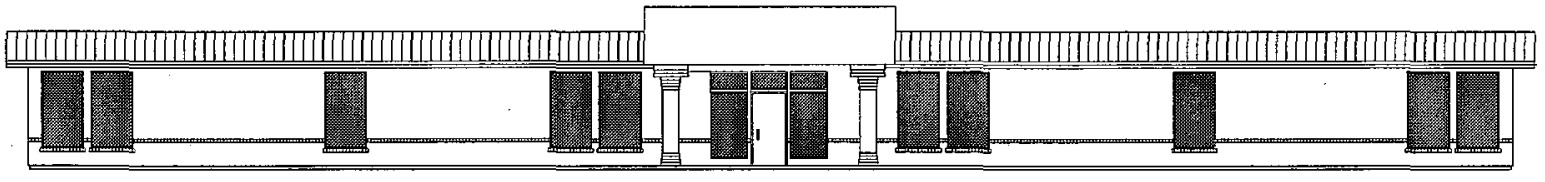

Figure 1. Office Building - 10,000 $\mathrm{ft}^{2}$ with $18 \%$ window-to-wall ratio

\section{Base Case}

The column under the heading "Low Base" shows the thermal building component characteristics and estimated costs for each of the major envelope components. Windows have both thermal performances (U-factor) and solar heat gain coefficients (SHGC). The specific characteristics under the Low Base are designated in the top two lines labeled "(std)". The current costing methodology for windows generally selects the window type that meets the performance requirements of the standard at the lowest cost. To avoid potential distortions in the incremental cost from one standard level to the next, an algorithm was developed that essentially searches for the pair of glazing types in the cost database that are just below and just above the U-factor and SHGC specified characteristics. The costs and performance measures are then averaged with a weighting procedure, the weights based upon how much each type deviates from the criteria. The weighted averaged U-factor and shading coefficient are labeled (cost) in the table. Using the weighting procedure, a representative cost per square foot of glazing was estimated to be $\$ 4.67$.

Costs for the other envelope components are based upon the cost model developed as part of the ASHRAE Standard 90.1-1999. The total cost for each component is simply the product of the area and the cost per square foot to achieve the specified thermal performance. Total cost is shown in the last line of the first panel-in this case $\$ 19,084$. As discussed in Section 4.1 above, this is not the total cost of the building envelope from an owner's point of view. It is, rather, the incremental cost relative to an uninsulated building using single-pane clear glass metal-framed windows.

The second panel in Table 7 summarizes the key inputs related to lighting. As discussed in Section 4, the lighting power density for offices under the 1989 standard and the LowEfficiency base case was assumed to be 1.63 watts per square foot. The first cost of the linear fluorescent and incandescent systems to meet this lighting density is estimated to be $\$ 1.57$ per square foot. In the same manner as the envelope, this cost figure should not be construed as the total cost to install all the lighting in a typical office building. It includes only linear fluorescent and a segment of incandescent lighting that are assumed to change under the more stringent requirements of 90.1-2001. Given this qualification, the total lighting cost for the building is $\$ 15,670$. 
Table 7. Engineering and Cost Summary

Small Office (WWR=0.18)

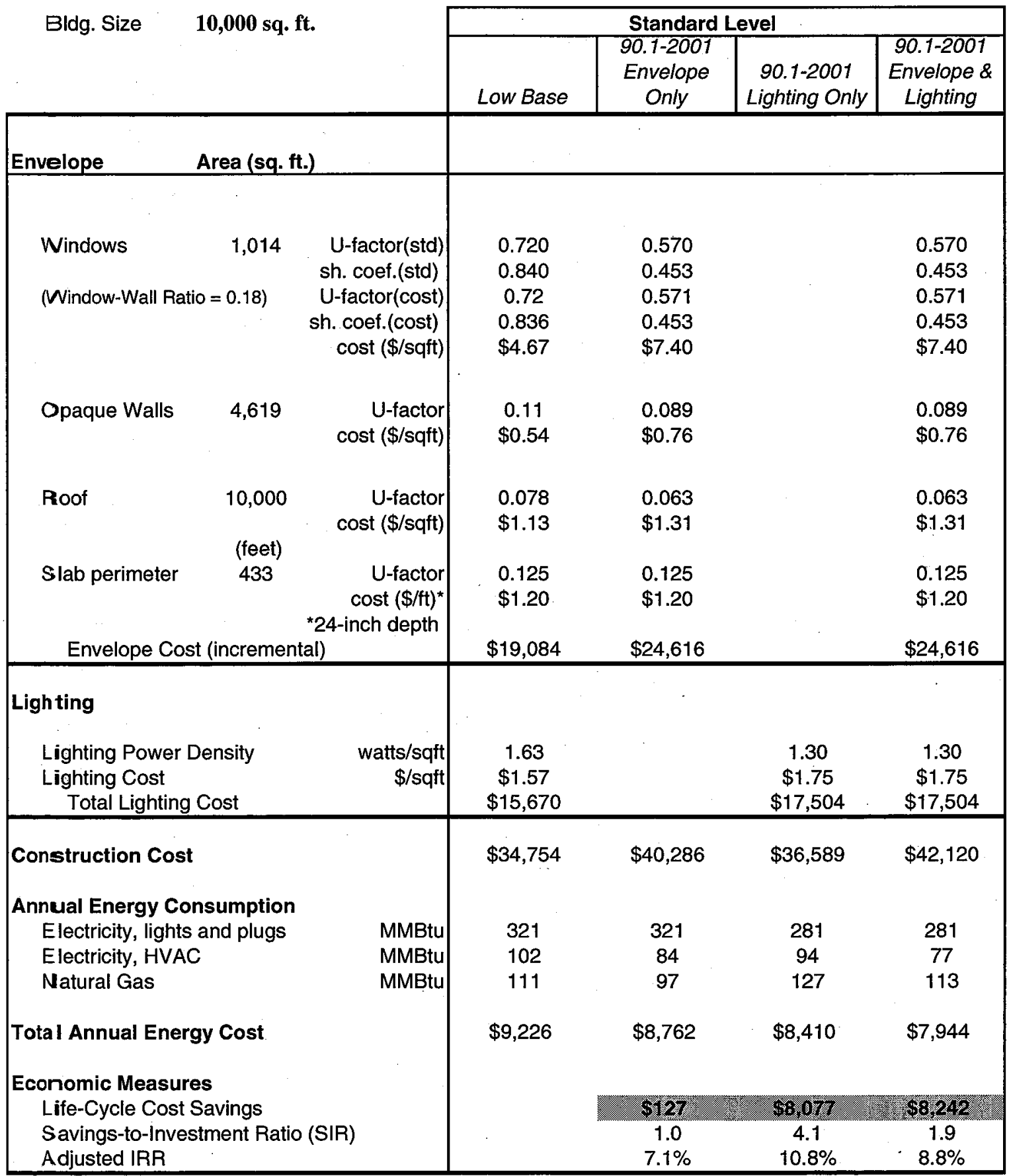

Notes:

1 Slab insulation is assumed in all cases, although not required in 90.1-2001. See text.

2. No economizer used

32004 electricity price $=6.7$ cents $/ \mathrm{kWh} \quad 2004$ gas price $=\$ 7.98 / \mathrm{MMBtu}$

4 Years for Analysis $=40 \quad$ Discount Rate $=\mathbf{7 . 0} \%$

Life-cycle cost savings includes replacement costs and residual values 
The bottom panel in the table shows the energy and cost implications for the entire building. The initial construction cost is the sum of the envelope and lighting costs, keeping in mind the incremental nature of this value. Annual energy consumption is shown in million Btu (MMBtu) for electricity and natural gas. Electricity consumption is shown for 1) lights and plugs and 2) HVAC. In these simulations, all buildings are assumed to be heated with natural gas. Electricity consumed for HVAC equipment, therefore, consists of ventilation fan and cooling use only. Natural gas is used for space heating and water heating, but differences among standards are entirely related to space heating. Total annual energy cost of $\$ 9,226$ is based upon fuel prices for 2004. The fuel prices used in this calculation are shown in note (2) at the bottom of the table.

\section{Envelope Only Case}

The second column under the section labeled "Standard Level" shows the envelope requirements and the estimated costs for ASHRAE Standard 90.1-2001. The U-factor requirements are all more stringent than the current practices that represent the LowEfficiency base case. To achieve the higher efficiency, first costs for envelope increases from $\$ 19,094$ to $\$ 24,616$. Window costs make up almost $\$ 3,000$ of this increase.

The bottom panel shows the energy consumption and cost impacts associated with this case. Electricity consumption for lights and plugs is unchanged from the baseline case. Electricity consumption for cooling and ventilation falls by $18 \mathrm{MMBtu}$, a result achieved from improvements in wall and roof insulation and the reduced solar gain through the windows. Natural gas consumption also falls as a result of the improved thermal performance of envelope components. Annual fuel costs decline by $\$ 464$ per year.

Calculated life-cycle costs are about $\$ 130$ lower as compared to the base case. The lifecycle costs include the increase in first costs of nearly $\$ 5,000$ less the ongoing energy cost savings discounted over the 40-year study period.

\section{Lighting Only Case}

In the lighting-only case, the approach described in Section 4.2 yields an incremental cost of $\$ 0.19$ per square foot as shown in column three of the lighting panel. The total incremental cost for the building is about $\$ 1,800$. Total electricity consumption falls by $48 \mathrm{MMBtu}$ per year for the lighting-only case. About $20 \%$ of this reduction stems from the lower cooling requirements because the efficient lights generate less heat. During the winter, less heat generated by the efficient lights requires more heat from the furnace; thus, natural gas consumption increases. However, the reduction in cooling cost is larger than the increase in heating cost. In combination with the reduced electricity use for the lighting, total fuel costs decline by about $\$ 800$ per year.

All three economic measures show that the more stringent lighting requirements associated with 90.1-2001 standards are highly cost effective. Life-cycle cost savings are just over $\$ 8,000$. The savings-to-investment ratio is about 4 . In other words, for every dollar of initial and (discounted) replacement investment cost, four dollars of 
(discounted) fuel expenditures are saved over the life of the building. The adjusted internal rate of return is $10.8 \% .^{11}$

\section{Envelope and Lighting Case}

The last column in the table shows the results of a simulation that combines both the envelope and lighting requirements of the ASHRAE 90.1-2001 standard. Annual energy expenditures are about $\$ 1300$ lower than the base case; life-cycle cost savings are over $\$ 8,000$. Note that the sum of the savings (from envelope and lighting changes) is greater than the LCC savings measured separately. This is because the reduction in lighting loads raises the balance point of the building and makes the envelope measures more cost-effective.

\subsubsection{Retail}

Table 8 shows the results for a single-story, 24,000 square foot, retail building. Figure 4 provides an illustration of a retail building with these characteristics. The base electricity consumption per square foot is higher in the retail building as compared to any of the office buildings due, in large part, to higher lighting levels. The lighting-only case for retail shows larger absolute reductions in total energy consumption, stemming largely from the relatively large difference in the LPD between the base case and 2001 standard. Even under the assumption that the reduction in LPD between the base case level of 2.36 watts $/ \mathrm{ft}^{2}$ and the 2001 level of 1.9 watts $/ \mathrm{ft}^{2}$ is accomplished entirely by changes to more efficient (and more expensive) technologies, the change is still cost effective. The savings-to-investment ratio is 3.7 and the adjusted IRR is nearly $10 \%$.

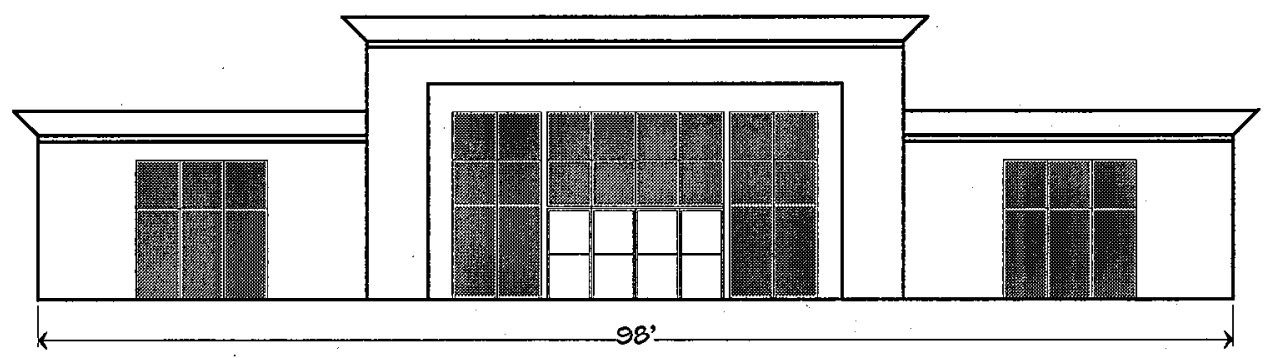

Figure 4. Retail Building $-24,000 \mathrm{ft}^{2}$ with $7 \%$ window-to-wall ratio

For the envelope-only case, although the requirements for the window U-factor and solar heat gain coefficient are more stringent under the 90.1-2001 standard as compared with the current Low-Efficiency practices, the smaller window area in most retail buildings (simulated here with a window-to-wall ratio of 0.07) diminishes the influence of this requirement on total energy use. The net effect is an increase in life-cycle cost of $\$ 3,800$. The combined effect of lighting and envelope, however, is a net decrease in lifecycle cost of just over $\$ 25,000$ relative to the base case.

\footnotetext{
${ }^{11}$ The difference between the IRR and AIRR can be considerable. In this case the IRR is about 50\%. The AIRR measure is more suitable for long-lived investments with its assumption that cost savings can be reinvested to achieve only a normal return over a long period of time. Another short-term measure is the payback period. In this case the payback is just over 2 years $(\$ 1,800 / \$ 800)$. The payback criterion is also not especially appropriate, however, for investments with a long life-those appropriate to the life-cycle of a building-as it ignores the benefits after the payback period.
} 
Table 8. Engineering and Cost Summary

Retail

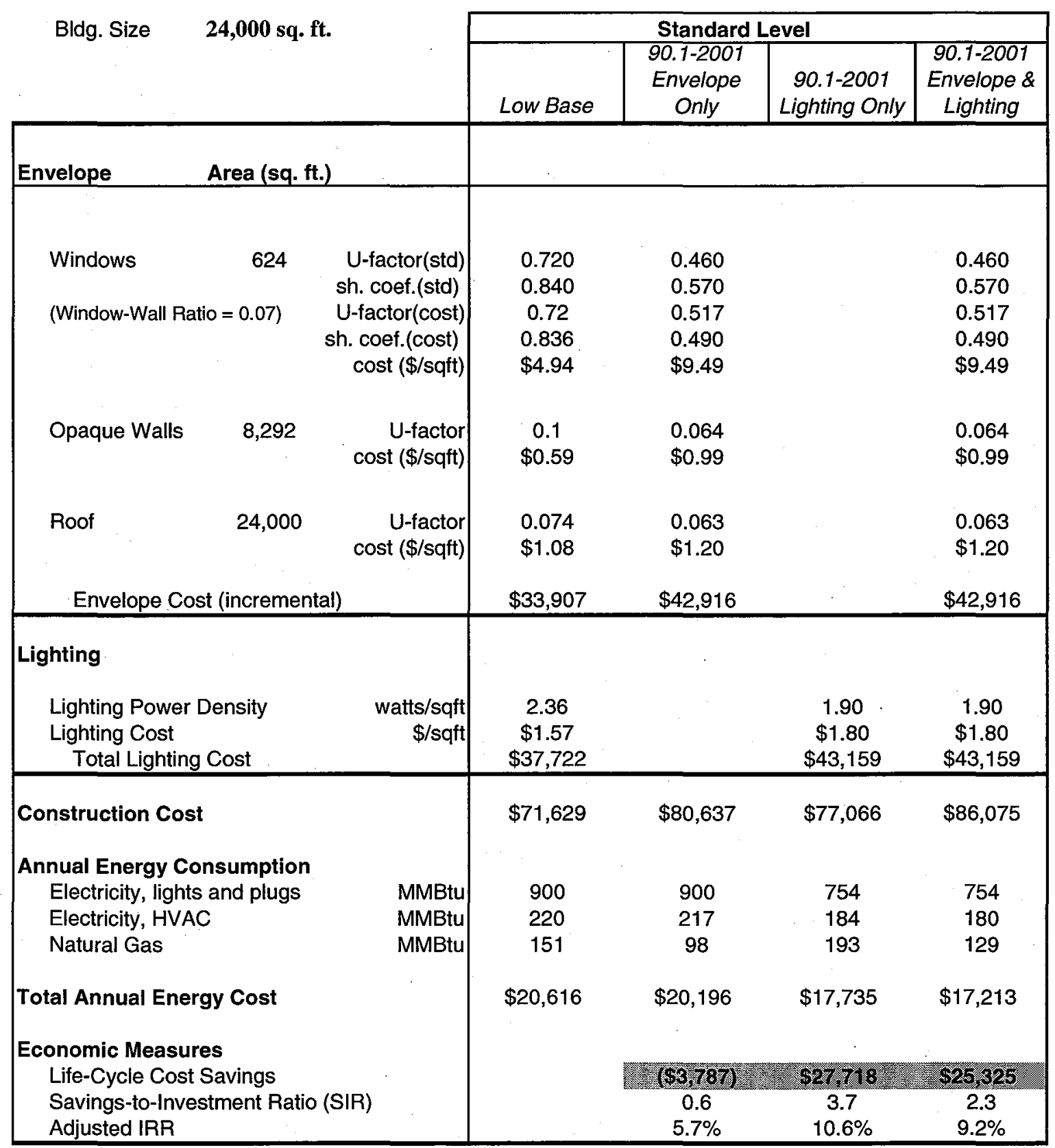

Notes:

1 No economizer used

22003 electricity price $=6.0$ cents $/ \mathrm{kWh} \quad 2003$ gas price $=\$ 7.04 / \mathrm{MMBtu}$

3 Years for Analysis $=40 \quad$ Discount Rate $=\mathbf{7 . 0 \%}$

Life-cycle cost savings includes replacement costs and residual values 


\subsection{The High-Efficiency Buildings Base Case}

The High-Efficiency base case is primarily characterized by larger office buildings and government buildings, such as school buildings; however, it also could include some well-engineered smaller office buildings and retail buildings. Detailed results for all of these building prototypes are included in Appendix C.

\subsubsection{Large Office Building}

The large office building analyzed has a larger footprint (20,000 square feet as compared to 10,000 square feet) and has three floors. Figure 3 illustrates an office building with these characteristics. Because it is assumed to use cooling equipment with a large capacity, it is modeled with an economizer. An economizer utilizes outside air for cooling once the temperature falls below a thermostat set point. Two variations in the window-to-wall ratio ( $18 \%$ and $38 \%$ ) were considered. The discussion below pertains to the building with $38 \%$ window-to-wall ratio.

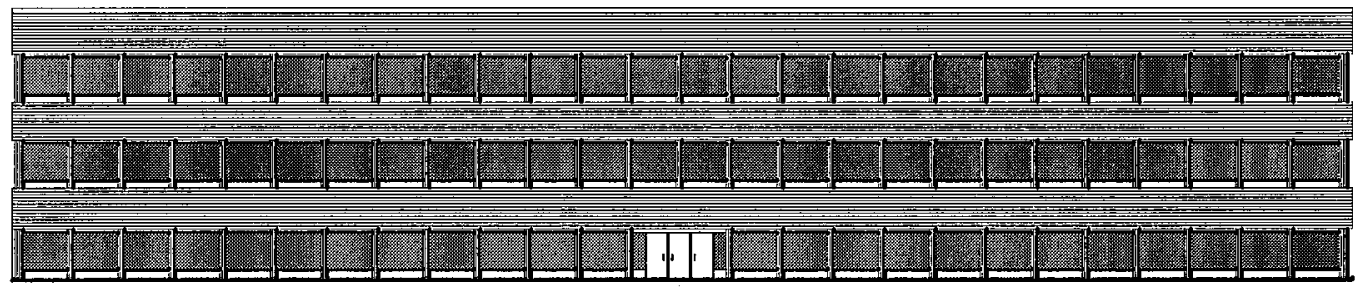

Figure 3. Office $-60,000 \mathrm{ft}^{2}$ with 3 stories and $38 \%$ window-to-wall ratio

\section{Base Case}

In Table 9, the column under the heading "High Base" shows the thermal building component characteristics and estimated costs for each of the major envelope components under the High-Efficiency base case. The specific characteristics under the High Base are designated in the top two lines labeled (std). The current costing methodology for windows generally selects the window type that meets the performance characteristics of the HighEfficiency baseline and the standard at the lowest cost. Using the weighting procedure described in 5.1.1, a representative cost per square foot of glazing was estimated to be $\$ 6.65$.

Total cost is shown in the last line of the first panel-in this case $\$ 100,884$. As discussed in Section 4.1 above, this is not the total cost of the building envelope from an owner's point of view. It is, rather, the incremental cost relative to an uninsulated building using single-pane clear glass windows.

The second panel in Table 9 summarizes the key inputs related to lighting. As discussed in Section 4, the lighting power density for large offices under the High-Efficiency base case was assumed to meet the 90.1-2001 standard requirements of 1.30 watts per square foot; thus, the base case lighting costs, $\$ 1.75$ per square foot, are the same under both the base case and the standard. 
Table 9. Engineering and Cost Summary

\section{Large Office (WWR=0.38)}

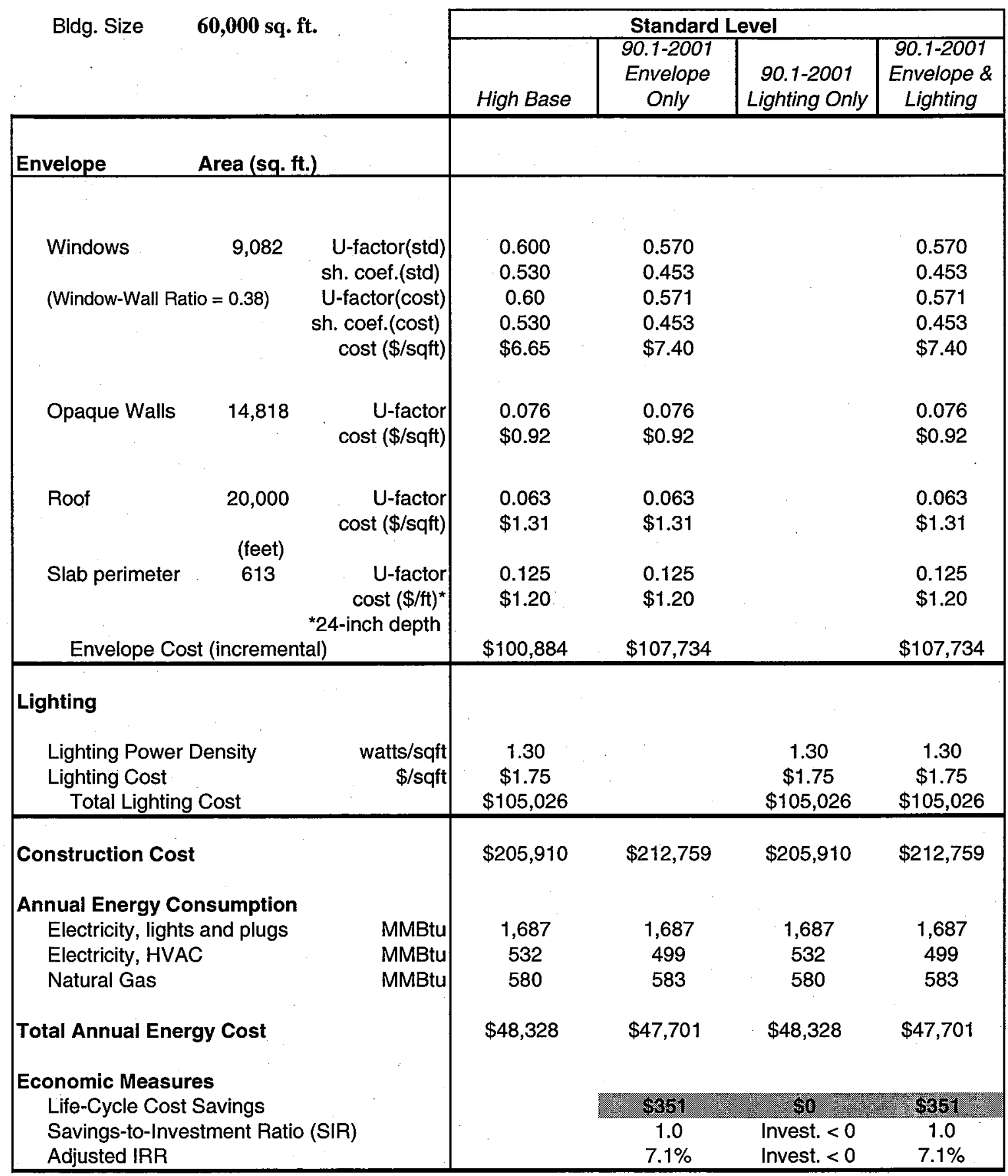

Notes:

1. Slab insulation is assumed in all cases, although not required in 90.1-2001. See text.

2 Economizer used

32004 electricity price $=6.7$ cents $/ \mathrm{kWh} \quad 2004$ gas price $=\$ 7.98 / \mathrm{MMBtu}$

4 Years for Analysis $=40 \quad$ Discount Rate $=\mathbf{7 . 0 \%}$

Life-cycle cost savings includes replacement costs and residual values 


\section{Envelope Only Case}

The second column under the section labeled "Standard Level" shows the envelope requirements and the estimated costs for standard ASHRAE 90.1-2001. Although some well-engineered buildings are most likely already meeting the fenestration U-factor requirements of the 90.1-2001 standard, it is possible that a number are not considering that that U-factor and SHGC requirements were significantly modified between the 1989 and 2001 versions of the ASHRAE standard. It is therefore assumed that the ASHRAE 90.1-2001 standard would require slightly lower U-factors and SHGC than is current practice. As for the wall and roof insulation requirements, it is assumed that the HighEfficiency base case practices meet or exceed the insulation requirements of 90.1-2001, thus no additional first costs would be required to meet the insulation requirements. To achieve the higher efficiency of the window, however, first costs for the envelope increase by about $\$ 7,000$.

The bottom panel shows the energy consumption and cost impacts associated with this case. Electricity consumption for lights and plugs is unchanged from the baseline case. Electricity consumption for cooling and ventilation falls by $33 \mathrm{MMBtu}$, a result achieved primarily from the reduced solar gain through the windows. The reduced solar gain, how ever, tends to increase natural gas consumption during the winter months, by about $1 \%$ according to the engineering simulation. Annual energy costs decline by $\$ 600$ per year.

The life-cycle cost savings are about $\$ 350$. The life-cycle costs include the increase in first cost of $\$ 7,000$ less the ongoing energy cost savings discounted over the 40-year study period.

\section{Envelope and Lighting Case}

The last column in the table shows the results of a simulation that combines both the envelope and lighting requirements of the ASHRAE 90.1-2001 standard. As there are no lighting impacts due the assumption that the High-Efficiency buildings are already meeting 2001 requirements, the total LCC savings is equal to the envelope-only case.

The cost savings for the for the high efficiency case for the office building with an $18 \%$ window-to-wall ratio are somewhat lower (See Appendix C), consistent with the smaller window area. Annual energy costs decline by about $\$ 300$ per year, and the life cycle costs fall by about $\$ 170$.

\subsubsection{Retail}

A retail building is modeled in the high efficiency case, as many national chain retailers can be expected to employ designs that consider energy efficiency. In the Highefficiency case for retail, as for offices, it was assumed that all of the characteristics with the exception of windows are meeting the 2001 envelope requirements. In the retail building case, however, the divergence between the high-efficiency practice and the 2001 standard was assumed to be greater than that for offices. Specifically, the shading coefficient of 0.79 was more representative of double-paned clear glass rather than low-e, 
tinted glass. The shading coefficient required under ASHRAE 90.1-2001 is 0.57 for buildings with a ratio of window to wall area of less than $10 \%$.

As shown in Table 10, these assumptions lead to reduction annual energy costs of more than $\$ 100$ per year and a reduction in life-cycle cost of over $\$ 800$. As in the office case, electricity use for heating, cooling and ventilation declines, but natural gas usage increases slightly. 
Table 10. Engineering and Cost Summary

Retail

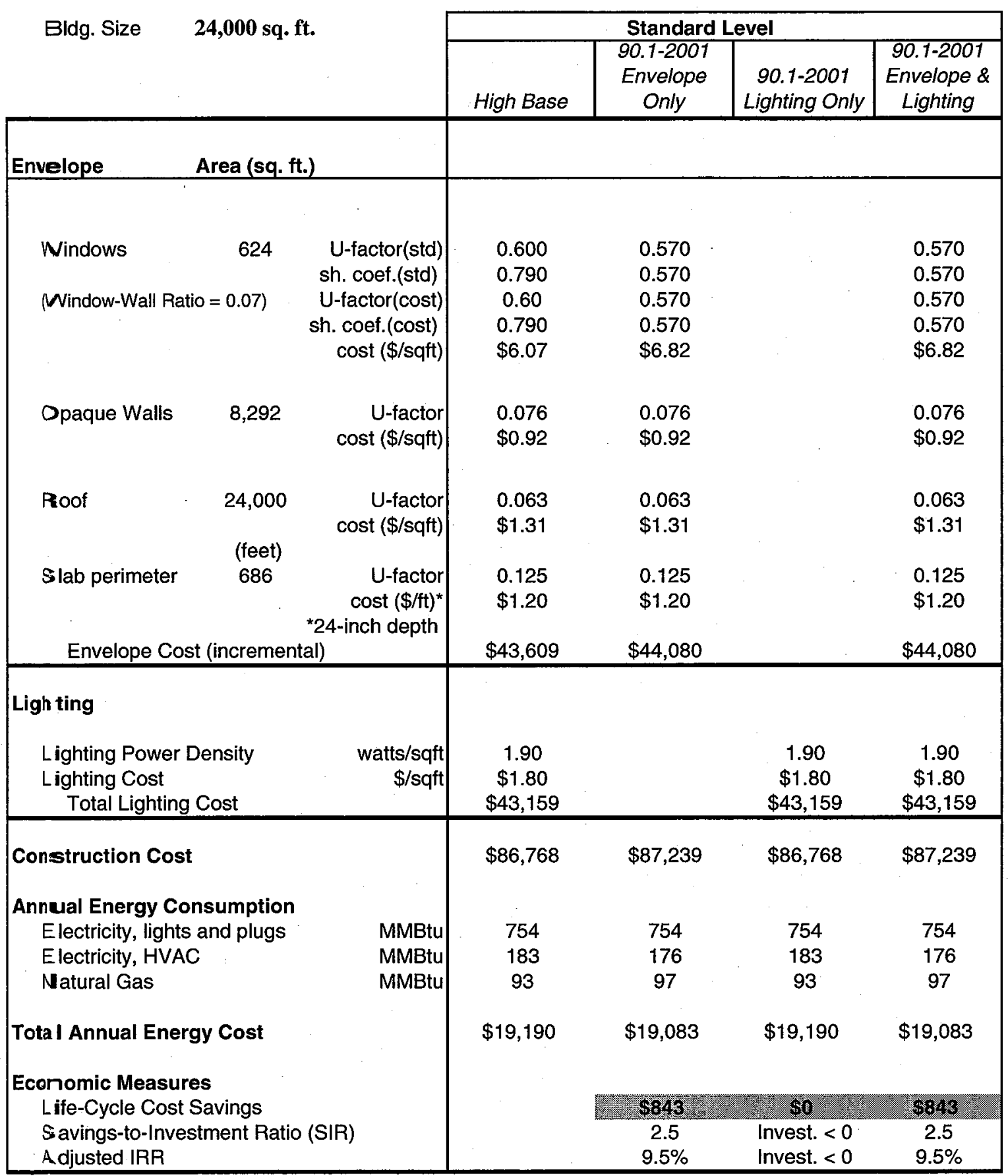

Notess:

1 Slab insulation is assumed in all cases, although not required in 90.1-2001. See text.

2 No economizer used

32004 electricity price $=6.7$ cents $/ \mathrm{kWh} \quad 2004$ gas price $=\$ 7.98 / \mathrm{MMBtu}$

4 Years for Analysis $=40 \quad$ Discount Rate $=\mathbf{7 . 0} \%$

Life-cycle cost savings includes replacement costs and residual values 


\subsubsection{Education}

Several education buildings were analyzed under the High Efficiency assumptions regarding the building envelope. As for offices, the principal requirement to meet the ASHRAE standard was assumed to involve selecting windows that will transmit less solar gain. For the two building configurations analyzed, the life-cycle costs increased on the order of $\$ 1,000$. Considering that a slight change in the assumptions regarding such things as glazing cost, thermostat settings, internal gains (e.g., electronic equipment in building), and infiltration rates could result in a positive LCC, this result is relatively uncertain as to whether this slight improvement in the windows provides net economic benefits. Note that the result is also dependent upon the discount rate chosen. As the tables in Appendix B show, the adjusted rates of return are in the range of $6.0 \%$ (rounded to the nearest tenth of a percentage point).

\subsection{Other Factors Impacting Benefits and Costs}

There are numerous areas of ASHRAE 90.1-2001 that are not easily valued and modeled with the quantitative approach taken in this study. Many of these other elements of the standard, however, do have quantitative economic and energy impacts. The following section briefly describes some probable energy benefits and costs of selected components of 90.1-2001 that are not captured in the previous analysis.

\subsubsection{Building Envelope}

The impact of air leakage requirements in ASHRAE 90.1-2001 are difficult to evaluate. As compared to the 1989 standard, air leakage requirements for windows are more stringent in the 2001 edition for four window types and less stringent in one other window type. In addition, air leakage for some door types are more stringent in the 2001 edition, while others are not. Very specific measurements would be required to understand how close current practice conforms to either of these sets of requirements.

ASHRAE 90.1-2001, however, also includes requirements for loading dock weather seals and vestibules, which would be applicable in South Dakota. If current practice is roughly equivalent to the 1989 standard, the net effect of adopting ASHRAE 90.1-2001 would be expected to reduce energy use.

ASHRAE 90.1-2001 requires that insulation be installed in substantial contact with the inside surface of cavities. It also requires that lighting fixtures, heating, ventilating, and air-conditioning, and other equipment not be recessed in such a manner as to affect the insulation performance. Finally, the 2001 edition bans installation of insulation on suspended ceilings with removable ceiling panels. The 1989 edition does not address these subjects. The ASHRAE 90.1-2001 insulation installation requirements are expected to save energy in commercial buildings relative to the ASHRAE 90.1-1989 baseline.

For cooler climates, ASHRAE 90.1-1989 requires between R-7 and R-8 slab-on-grade insulation, while ASHRAE 90.1-2001 has no such requirements. A reduction in slab 
insu lation would, by itself, be expected to result in higher heating loads in cold climates with ASHRAE 90.1-2001; however, there may be cooling benefits.

The net efficiency improvement resulting from these envelope upgrades to meet 90.1 2001 standard are expected to be positive, but insufficient information prevents further quantification.

\subsubsection{Lighting}

One of the more significant lighting requirement elements of ASHRAE 90.1-2001 not included in the quantitative results is lighting control requirement. Lighting controls, such as occupancy sensors, have the potential to significantly reduce energy use by switching off electrical lighting loads when a space is vacated. Manufacturers claim savings of $15 \%$ to $70 \%$, although there is little published research to support the magnitude or timing of reductions. Energy savings and performance are directly related to the total wattage of the load being controlled, effectiveness of the previous control method, occupancy patterns within the space, and proper sensor commissioning. Case studies of energy savings have had varied results due largely to differences in human factors, previous control strategies and proper sensor commissioning (Floyd 1997).

In the area of lighting controls, ASHRAE 90.1-2001 specifies that a building utilize a "whole-building controller," at a minimum. Although a whole building controller is a relatively low-cost lighting control solution, it is not very practical for many applications and therefore it is unlikely that this would be the alternative of choice for most building designs. More likely, a building design would incorporate something like occupancy sens ors; however, this is above and beyond the minimal ASHRAE requirement, which makes the evaluation of the code impacts with regard to lighting controls difficult to assess. It is expected, however, that including a lighting control requirement will save energy compared to a standard that does not include this requirement.

\subsubsection{Mechanical and SWH}

There are significant changes to HVAC and SWH equipment efficiencies between 90.11989 and 90.1-2001; however, most of this equipment is covered by federal man ufacturing standards whose adoption by federal statute will set their efficiencies at least as high as those in ASHRAE 90.1-2001 within a relatively short time frame. Chillers, however, which are not covered under manufacturing standards, have significantly higher efficiencies under 90.1-2001. In addition, 90.1-2001 sets requirements for heat rejection equipment (fluid coolers and cooling towers) as well as for absorption chillers that were not addressed in 90.1-1989. Two other significant additions to 90.1-2001 include more stringent performance requirements for variable speed fan systems as well as the addition of requirements for heat recovery. In terms of usability, the 90.1-2001 Standard has dropped much of the non-enforceable language as well as some difficult to enforce requirements (like system sizing) that were in the 90.11989 standard. A description of these and other differences between the mechanical system requirements in 90.1-1989 and 90.1-1999 (very similar to 2001) can be reviewed online at http://www.energycodes.gov/implement/determinations com.stm. 


\subsubsection{Scope of Standard}

One dominating factor influencing potential impacts of costs and benefits of adopting ASHRAE 90.1-2001 is the inclusion of alterations and renovations to the scope of the standard. This greatly expands the scope of the standard beyond ASHRAE 90.1-1989, which only applied to new buildings or new portions of existing buildings (additions). While it is difficult to quantify the energy efficiency impact of alterations and renovations, the U.S. Census Bureau 1997 Construction Geographic Area Series reports that the dollar value of commercial construction devoted to additions, alterations, or reconstruction in South Dakota was about $\$ 180$ million in 1997, as compared to new building construction valued at $\$ 450$ billion (2000c) If the value of annual investment in building alterations and renovations is a good indicator of its impact on energy use, then the expansion of this code to existing buildings could produce nearly $40 \%$ more savings than if it were applied exclusively to new buildings. 


\subsection{Qualitative Considerations}

In comparing ASHRAE 90.1-2001 to ASHRAE 90.1-1989, various revisions have been made in an effort to make the standard clearer and easier to enforce. For example, the inclusion of specific direction on how to calculate luminaire power in Standard 90.1-2001 is expected to eliminate some under-calculation of lighting power, which may lead to grea ter energy savings. In addition, various language and formatting changes have been made to make the standard easier to apply.

Whi le the ASHRAE 90.1-1989 Standard provided climate-specific guidance by using exarnple cities, the ASHRAE 90.1-2001 Standard provides requirements in terms of "clirnate bins" that cover a larger area. This allows builders to more easily find an appropriate climate for the area in which they are building. The ASHRAE 90.1-2001 Standard also simplifies the code compliance for smaller-scale construction by providing a "S implified Approach Option for HVAC Systems." This section condenses the mec hanical system requirements for a large class of simple systems.

ASHRAE Standard 90.1-2001 is written in mandatory, enforceable language. ASHRAE Standard 90.1-1989 contains guidance written as suggestive statements, which may complicate enforcement and compliance if not properly defined and revised. ASHRAE 90.1 -2001 also provides specific guidance for applying the code to existing building alterations and additions. From an energy savings standpoint, changes that make ASHRAE Standard 90.1-2001 easier to understand and enforce may have a positive impact on energy savings. 
!

)

1
1
1
$\vdots$
$j$ 


\subsection{Conclusions}

The results of this limited study appear to suggest that even though there is currently no man datory statewide energy code in South Dakota, many architectural and engineering firms design and construct commercial buildings that meet or exceed these requirements prescribed in ANSI/ASHRAE/IESNA 90.1-2001 Energy Standard for Buildings except Low-Rise Residential Buildings. Windows may be the chief exception in that adoption of 90.1-2001 would require improvements in the thermal integrity and SHGC of windows installed in High-Efficiency buildings. For the large office and retail buildings, improved windows would lower both energy costs and life-cycle costs and reduced energy costs in the education buildings. In general, it appears that updating the current recommended standard would have small positive impacts, both in terms of economic and energy savings for the majority of buildings conforming to our High-Efficiency prototypes.

However, there is a segment of the new commercial construction market in which many buildings are built with lower overall efficiency (Low-Efficiency buildings). For these building types--smaller offices, retail strip malls, and other small commercial buildings-the adoption of a recent ASHRAE standard would have net benefits. These benefits are most likely achieved only if the code is adopted and enforced at a local level.

The lighting requirements of 90.1-2001 appear to be highly cost-effective for these building types, particularly those that are being built at a Low-Efficiency level. When lighting and envelope requirements are combined, all of the Low-Efficiency buildings simulated display savings in energy use, annual fuel cost, and life-cycle costs.

Perhaps one of the most compelling arguments for considering the adoption of the updated 90.1-2001 standard would include the qualitative benefits described in Section 6. Con sidering that South Dakota has never had a statewide commercial building energy standard, the adoption of such a standard would clearly bring the aspect of energy efficiency into more prominence by the building community. 



\subsection{References}

American Society of Heating, Refrigerating and Air-Conditioning Engineers (ASHRAE) and Illuminating Engineering Society of North America (IESNA). 2001. ASHRAE Standard Energy Standard for Buildings Except Low-Rise Residential Buildings.

Cort, K. et. al. 2004. Analysis of Potential Benefits and Costs of Updating the Recommended Commercial Building Energy Standard in North Dakota. Pacific Northwest National Laboratory, PNNL-14637, April 2004.

Energy Information Administration (EIA). 2004a. "Annual Electric Utility Report," and EIA-826, "Monthly Electric Utility Sales and Revenue Report with State Distributions." EIA-861, U.S. Department of Energy. Summer, 2004. Washington D.C.

Energy Information Administration (EIA). 2004b. Annual Energy Outlook 2003 with Projections to 2025. U.S. Department of Energy. December 2004. Washington D.C.

Ene rgy Information Administration (EIA). 2004c. "State Energy Profiles," U.S. Department of Energy. August 2004. Washington D.C.

Floyd, D. et. al. "Measured Field Performance and Energy Savings of Occupancy Sensors: Three Case Studies." FSEC-PF309, 1997. [Online]. Available: http://www.fsec.ucf.edu/ bdac/pubs/PF309/PF309.htm, accessed 02/01.

National Institute of Standards and Technology (NIST). April 2003. "Energy Price Indi ces and Discount Factors for Life-Cycle Cost Analysis." NISTIR 85-3273-16, U.S. Department of Commerce,. Washington D.C.

Office of Management and Budget (OMB). 1992. Guidelines and Discount Rates for Ben efit-Cost Analyses of Federal Programs. OMB Circular A-94. [Online]. Available: http://www.whitehouse.gov/OMB/circulars/a094/a094.html

Somasundaram, S. et. al. 2000. Screening Analysis for EPACT-Covered Commercial HVAC and Water-Heating Equipment. Pacific Northwest National Laboratory, PNNL-13232. April 2000.

U.S. Bureau of Labor Statistics (BLS). 2005. Producer Price Index Industry Series. Pub lic Use Data available on BLS website. [Online]. Ava.ilable: $\underline{\text { http://data.bls.gov/labjava/outside/jsp?survey=pc. }}$.

U.S. Census Bureau (Census). 2000a. United States Census 2000. U.S. Department of Commerce, April 2000, Washington D.C.

U.S. Census Bureau (Census). 2000b. "1997 Economic Census Construction Geo graphic Area Series.” U.S. Department of Commerce, March 2000. Washington D.C.Energy 
U.S. Department of Energy (DOE). 2000. January 2000. "Fluorescent Lamp Ballast Technical Support Document." DOE website. [Online].

Available: http://www.eren.doe.gov/buildings/codes standards/reports/ballasts/index.htm 


\section{Appendix A \\ Glossary of Selected Terms}


1

1

I

। 


\section{Glossary}

Ballast: a device used in conjunction with an electric-discharge lamp to cause the lamp to start and operate under the proper circuit conditions of voltage, current, wave form, electrode heat, etc.

Buil ding Envelope: the exterior plus the semi-exterior portions of a building. For the purposes of determining building envelope requirements, the classifications are defined as follows:

(a) building envelope, exterior: the elements of a building that separate conditioned space from the exterior.

(b) building envelope, semi-exterior: the elements of a building that separate conditioned space from unconditioned space or that enclose semi-heated spaces through which thermal energy may be transferred to or from the exterior, or to or from unconditioned spaces, or to or from conditioned spaces.

CDD50 Cooling Degree-Day base $50^{\circ} \mathrm{F}$ : for any one day, when the mean temperature is more than $50^{\circ} \mathrm{F}$, there are as many degree-days as degree Fahrenheit temperature difference between the mean temperature for the day and $50^{\circ} \mathrm{F}$. Annual cooling degreedays (CDDs) are the sum of the degree-days over a calendar year.

C-factor (thermal conductance): time rate of steady state heat flow through unit area of a material or construction, induced by a unit temperature difference between the body surfaces. Units of $\mathrm{C}$ are $\mathrm{Btu} / \mathrm{h} \cdot \mathrm{ft}^{2 \cdot}{ }^{\circ} \mathrm{F}$. Note that the $\mathrm{C}$-factor does not include soil or air films.

Envelope performance factor: the trade-off value for the building envelope performance compliance option calculated using the procedure in Section 5 of the ASHRAE/IESNA Standards 90.1-1999.

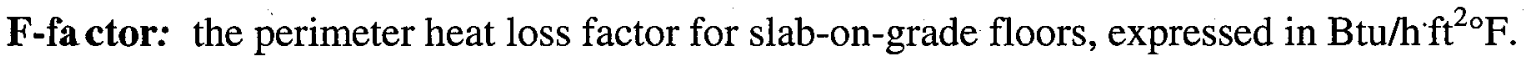

HDD65 Heating Degree-Day base $65^{\circ} \mathrm{F}$ : for any one day, when the mean temperature is less than $65^{\circ} \mathrm{F}$, there are as many degree-days as degree Fahrenheit temperature difference between the mean temperature for the day and $65^{\circ} \mathrm{F}$. Annual heating degreedays (HDDs) are the sum of the degree-days over a calendar year.

HVAC system: the equipment, distribution systems, and terminals that provide, either collectively or individually, the processes of heating, ventilating, or air conditioning to a building or portion of a building.

Life Cycle Cost (LCC) analysis: a method of analyzing the cost of a system or a product over its entire lifespan. LCC enables you to define the elements included in the lifespan of a system or product, and assign equations to each element. These equations represent the calculation of the cost of that particular element. 
Shading Coefficient (SC): the ratio of solar heat gain at normal incidence through glazing to that occurring through $1 / 8$ in. thick clear, double-strength glass. Shading coefficient, as used herein, does not include interior, exterior, or integral shading devices.

U-factor (thermal transmittance): heat transmission in unit time through unit area of material or construction and boundary air films, induced by unit temperature difference between the environment and each side. Units of $\mathrm{U}$ are $\mathrm{Btu} / \mathrm{h}{ }^{\circ} \mathrm{F}$.

Source: For details refer to ASHRAE STANDARD, Energy Standard for Buildings Except Low-Rise Residential Buildings. I-P edition.. American Society of Heating, Refrigerating and Air-Conditioning Engineers, Inc. 1999. 


\section{APPENDIX B Low-Efficiency Base Case Results}


$j$

1

1

1
$\vdots$ 
Small Office (WWR=0.18)

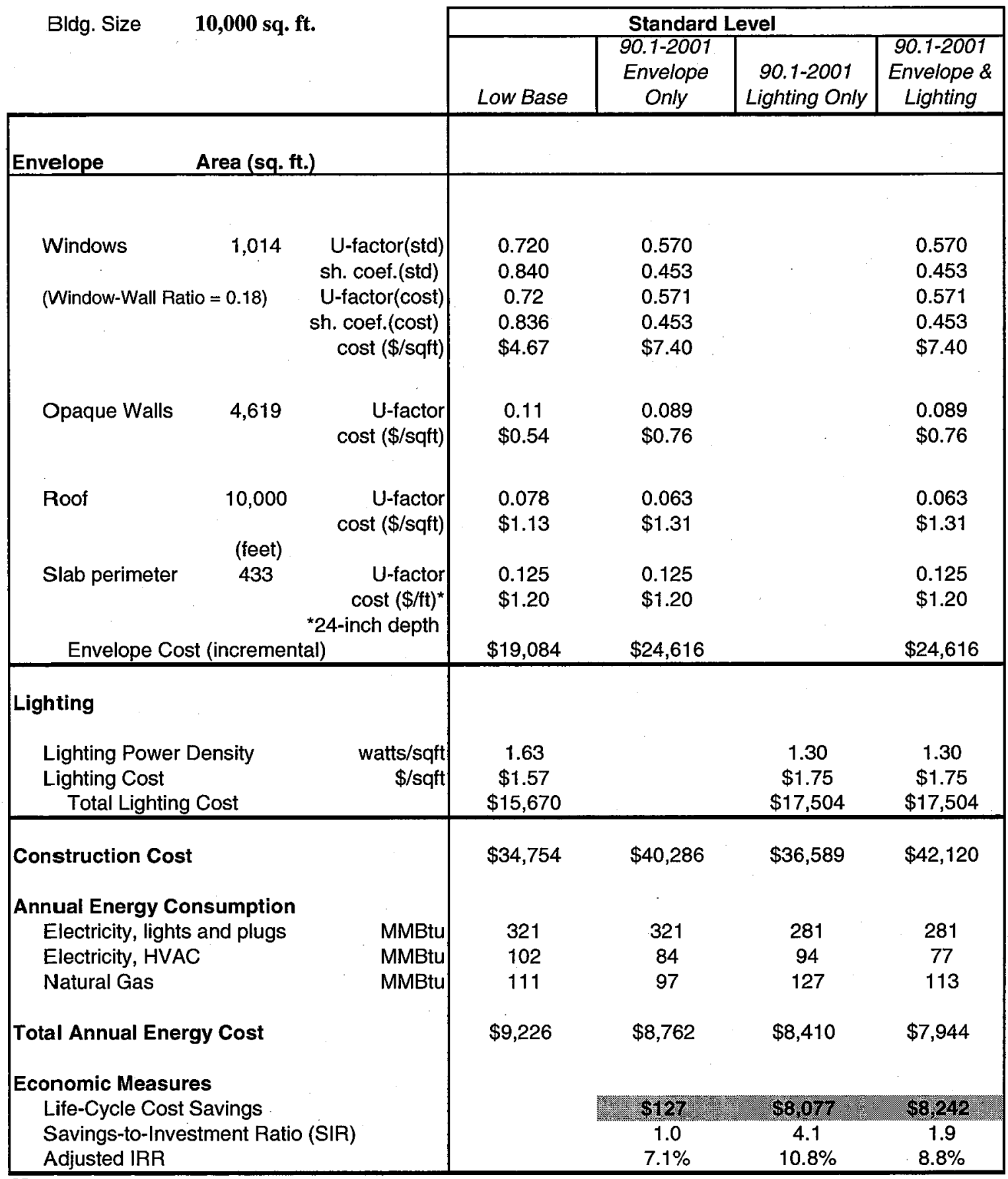

Notes:

1 Slab insulation is assumed in all cases, although not required in 90.1-2001. See text.

2 No economizer used

32004 electricity price $=6.7$ cents $/ \mathrm{kWh} \quad 2004$ gas price $=\$ 7.98 \mathrm{MMBtu}$

4 Years for Analysis $=40 \quad$ Discount Rate $=\mathbf{7 . 0 \%}$

Life-cycle cost savings includes replacement costs and residual values 


\section{Small Office $(W W R=0.38)$}

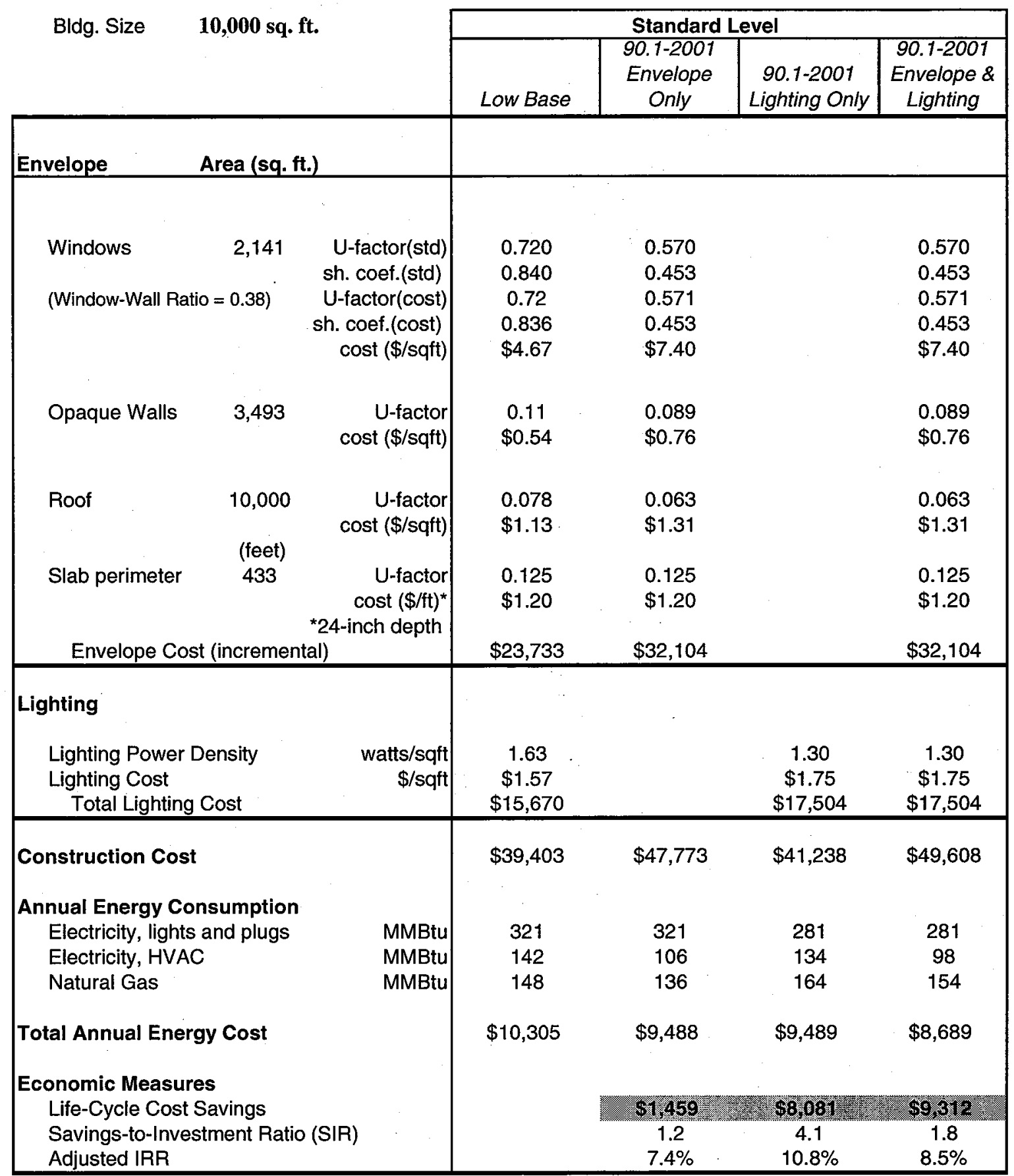

Notes:

1 Slab insulation is assumed in all cases, although not required in 90.1-2001. See text.

2 No economizer used

32004 electricity price $=6.7$ cents $/ \mathrm{kWh} \quad 2004$ gas price $=\$ 7.98 / \mathrm{MMBtu}$

4 Years for Analysis $=40 \quad$ Discount Rate $=\mathbf{7 . 0} \%$

Life-cycle cost savings includes replacement costs and residual values 


\section{Large Office (WWR=0.18)}

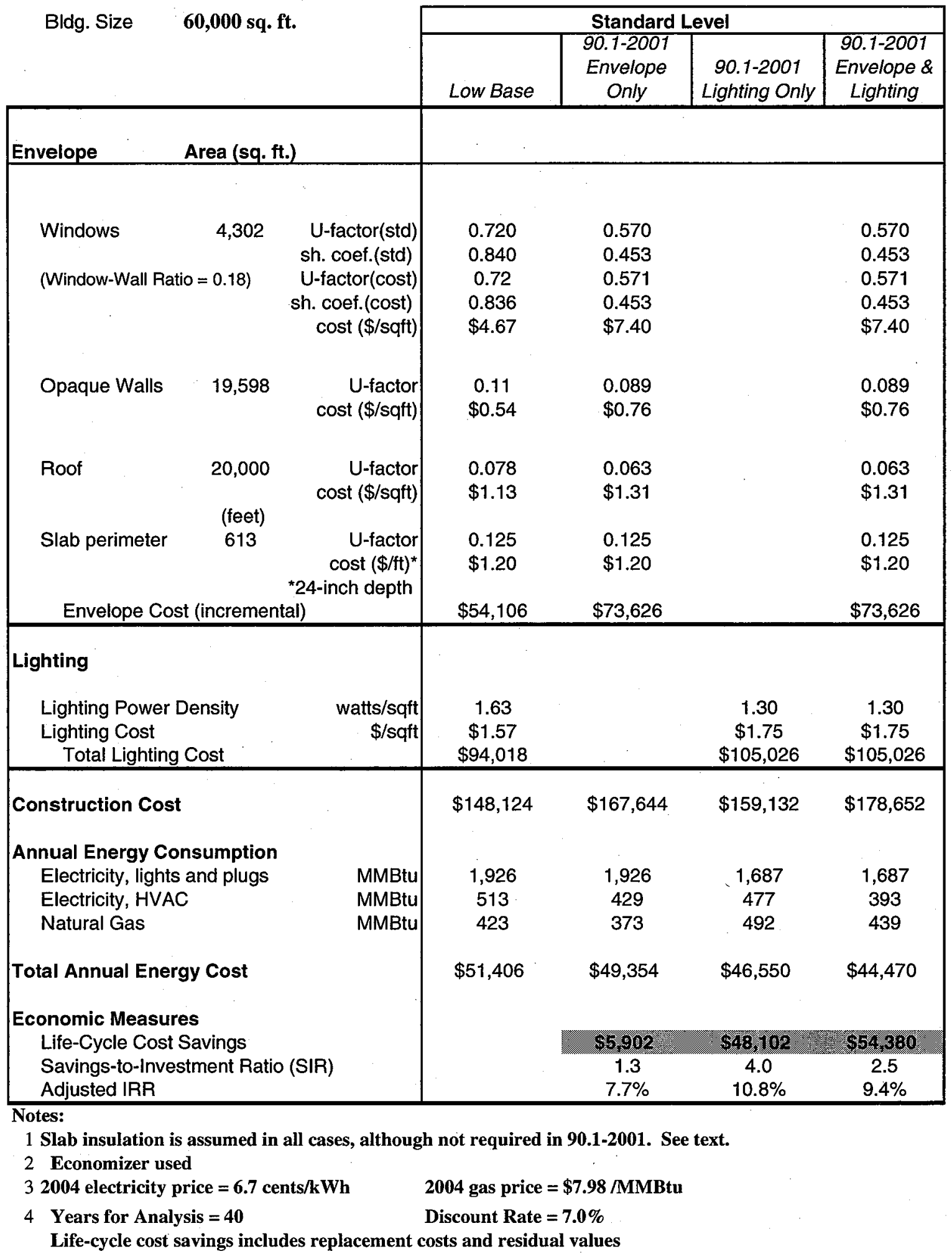




\section{Large Office (WWR=0.38)}

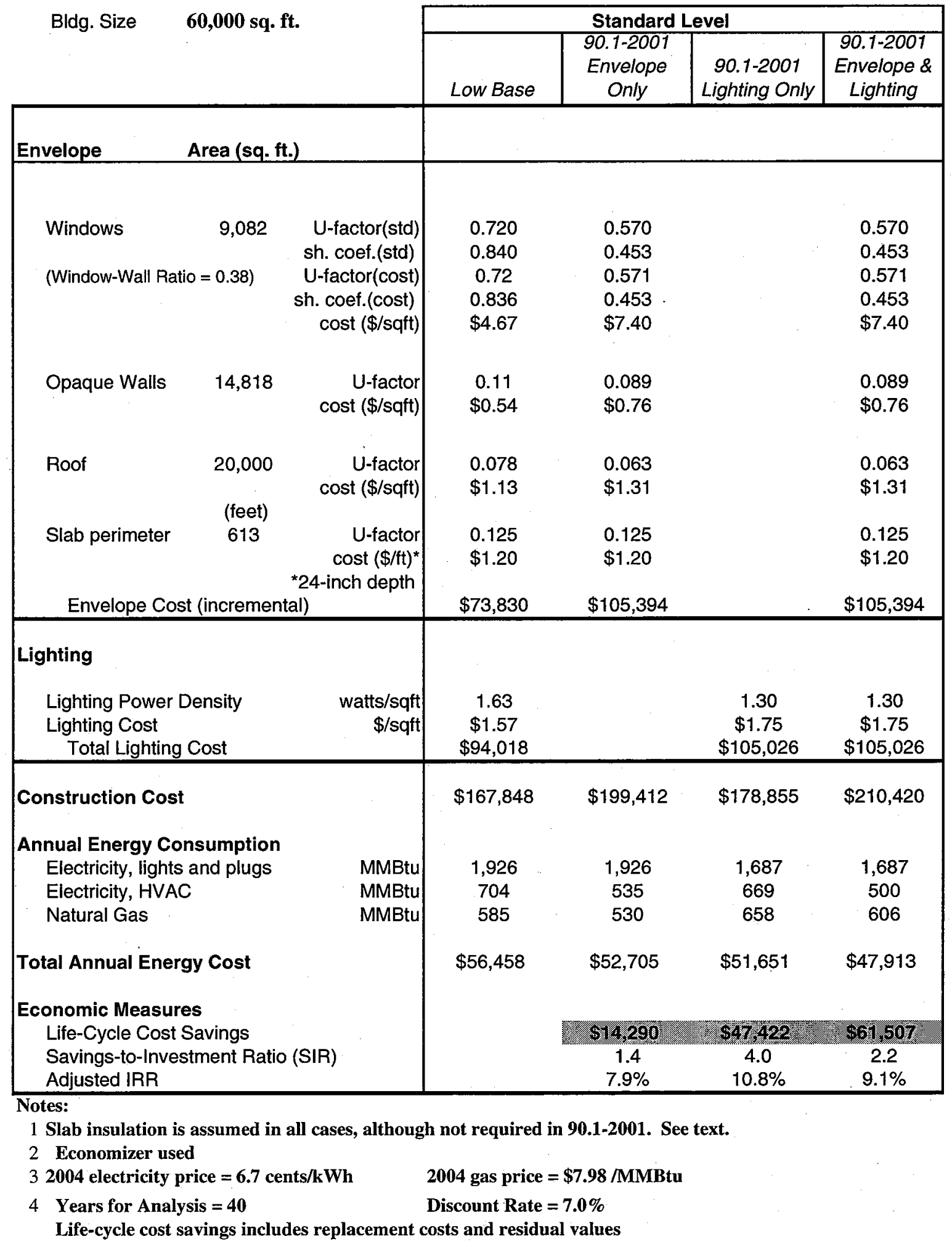




\section{Retail}

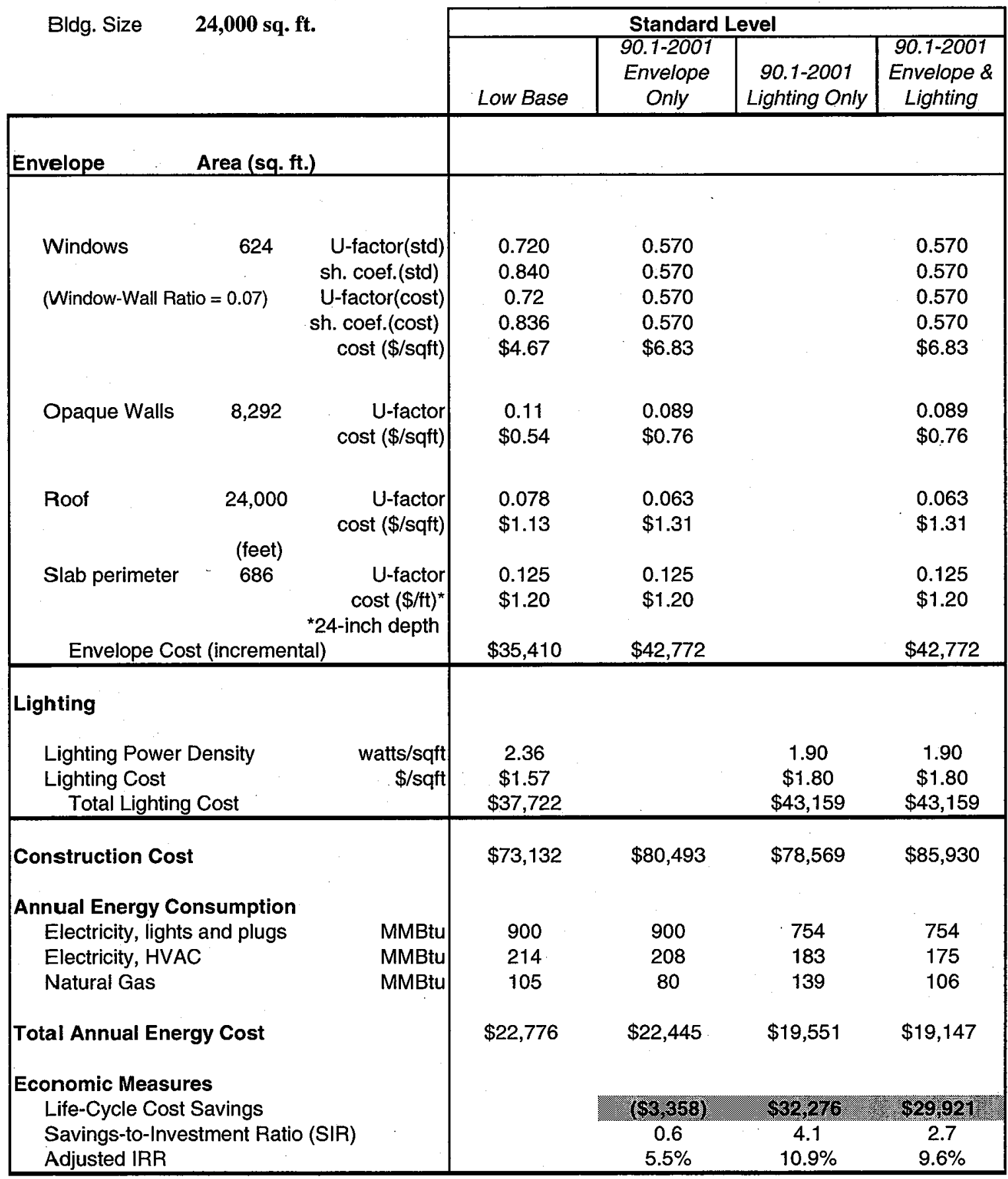

Notes:

1 Slab insulation is assumed in all cases, although not required in 90.1-2001. See text.

2 No economizer used

32004 electricity price $=6.7$ cents $/ \mathbf{k W h} \quad 2004$ gas price $=\$ 7.98 / \mathrm{MMBtu}$

4 Years for Analysis $=\mathbf{4 0}$ Discount Rate $\mathbf{= 7 . 0 \%}$.

Life-cycle cost savings includes replacement costs and residual values 


\section{Education (elementary)}

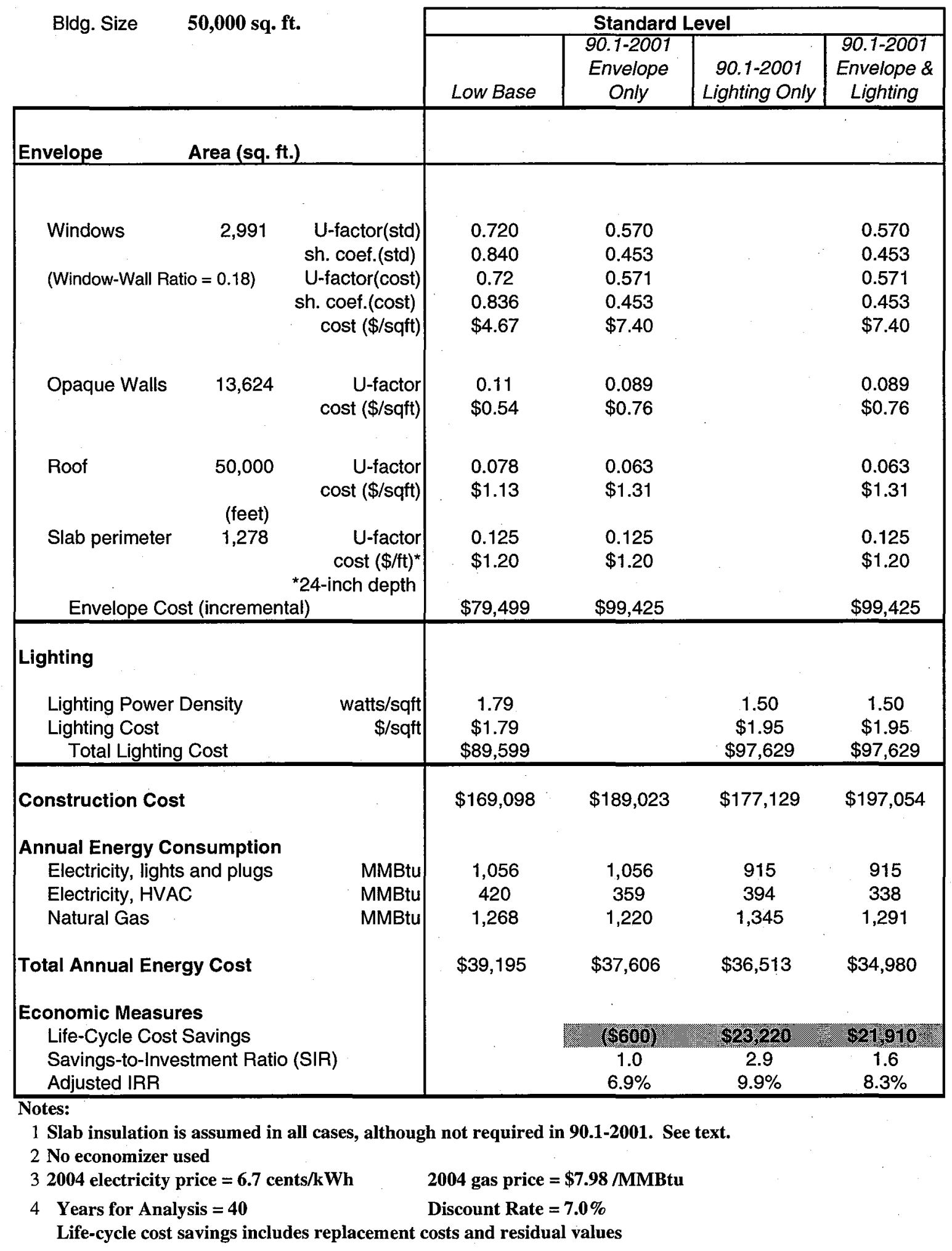




\section{Appendix C \\ High-Efficiency Base Case Results}



Small Office $(W W R=0.18)$

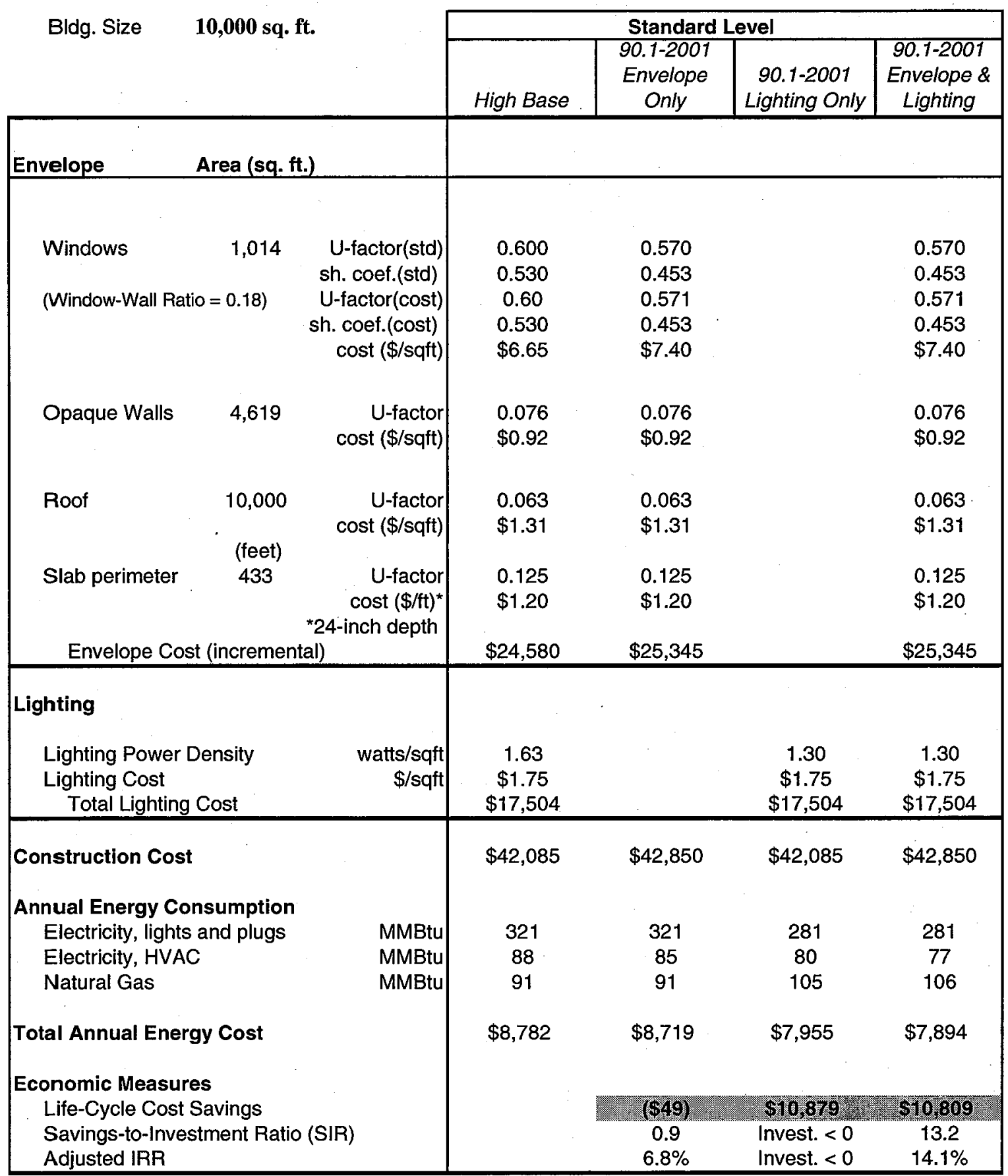

Notes:

1 Slab insulation is assumed in all cases, although not required in 90.1-2001. See text.

2 No economizer used

32004 electricity price $=6.7$ cents $/ \mathrm{kWh} \quad 2004$ gas price $=\$ 7.98 / \mathrm{MMBtu}$

4. Years for Analysis $=\mathbf{4 0}$ Discount Rate $=\mathbf{7 . 0 \%}$

Life-cycle cost savings includes replacement costs and residual values

C.1 


\section{Small Office (WWR=0.38)}

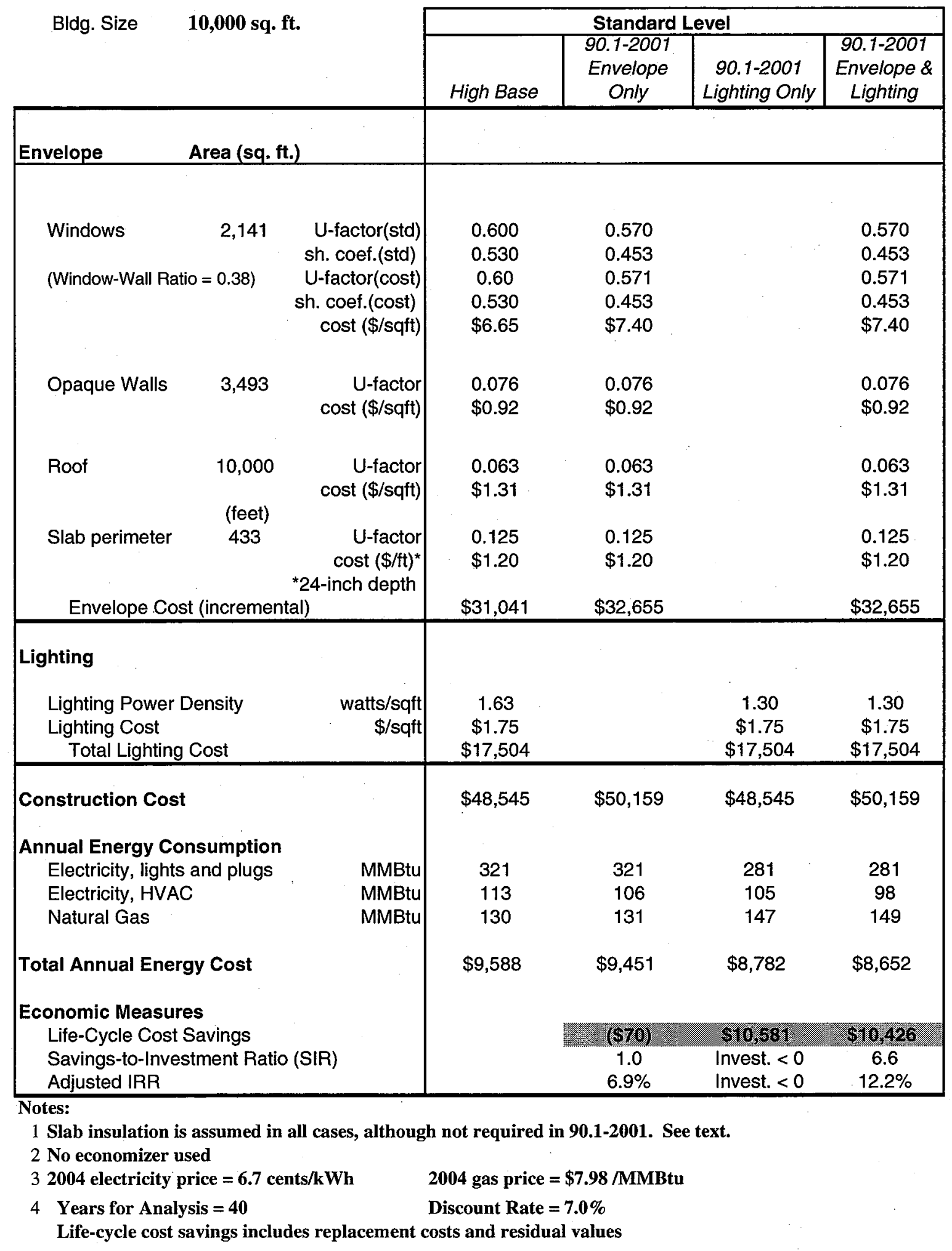




\section{Large Office (WWR=0.18)}

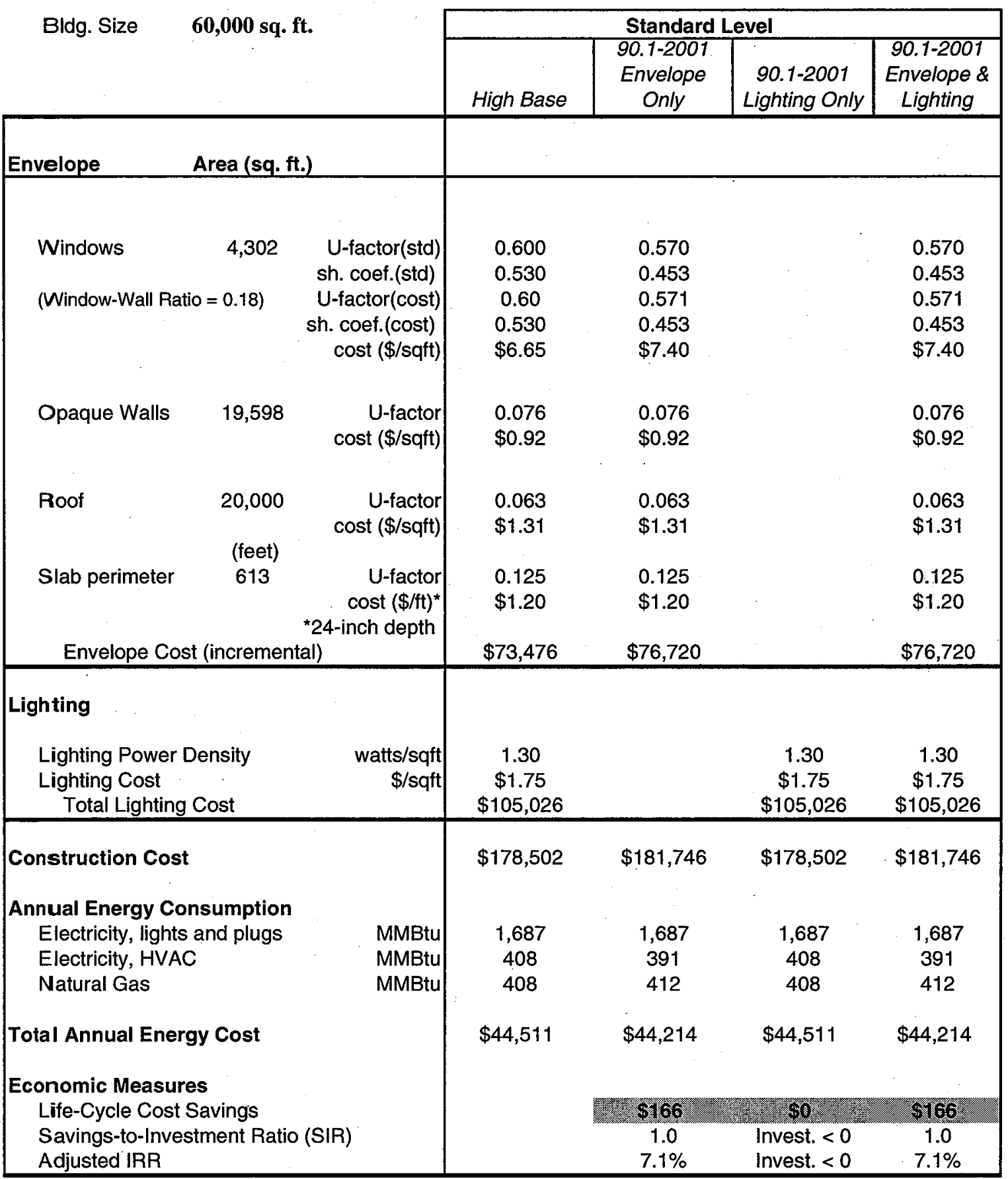

Notes:

1 Slab insulation is assumed in all cases, although not required in 90.1-2001. See text.

2 Economizer used

32004 electricity price $=6.7 \mathrm{cents} / \mathrm{kWh} \quad 2004$ gas price $=\$ 7.98 / \mathrm{MMBtu}$

4 Years for Analysis $=\mathbf{4 0} \quad$ Discount Rate $=\mathbf{7 . 0} \%$

Life-cycle cost savings includes replacement costs and residual values 


\section{Large Office (WWR=0.38)}

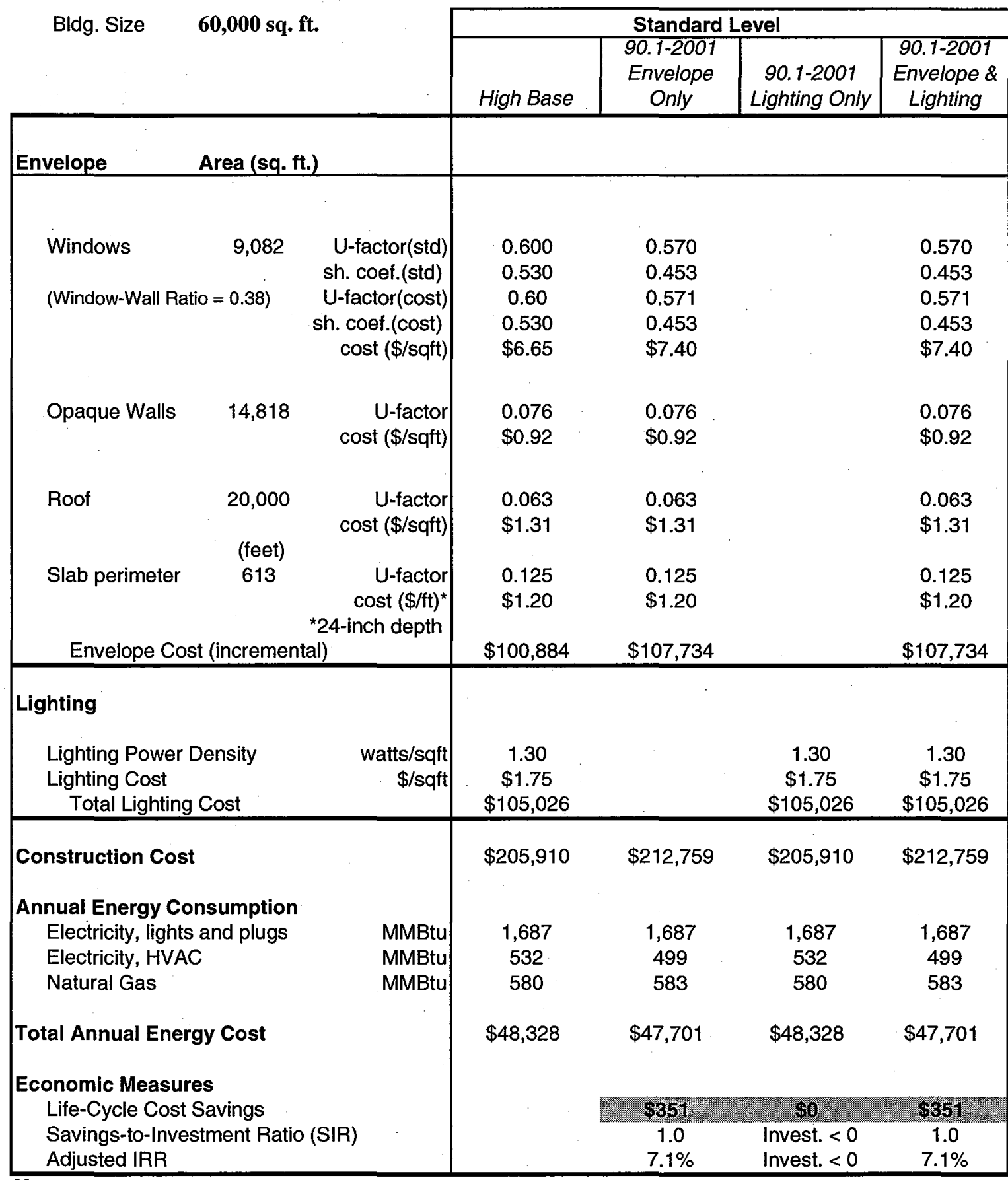

Notes:

1 Slab insulation is assumed in all cases, although not required in 90.1-2001. See text.

2 Economizer used

32004 electricity price $=6.7$ cents $/ \mathrm{kWh} \quad 2004$ gas price $=\$ 7.98 / \mathrm{MMBtu}$

4 Years for Analysis $=40 \quad$ Discount Rate $=\mathbf{7 . 0} \%$

Life-cycle cost savings includes replacement costs and residual values 


\section{Retail}

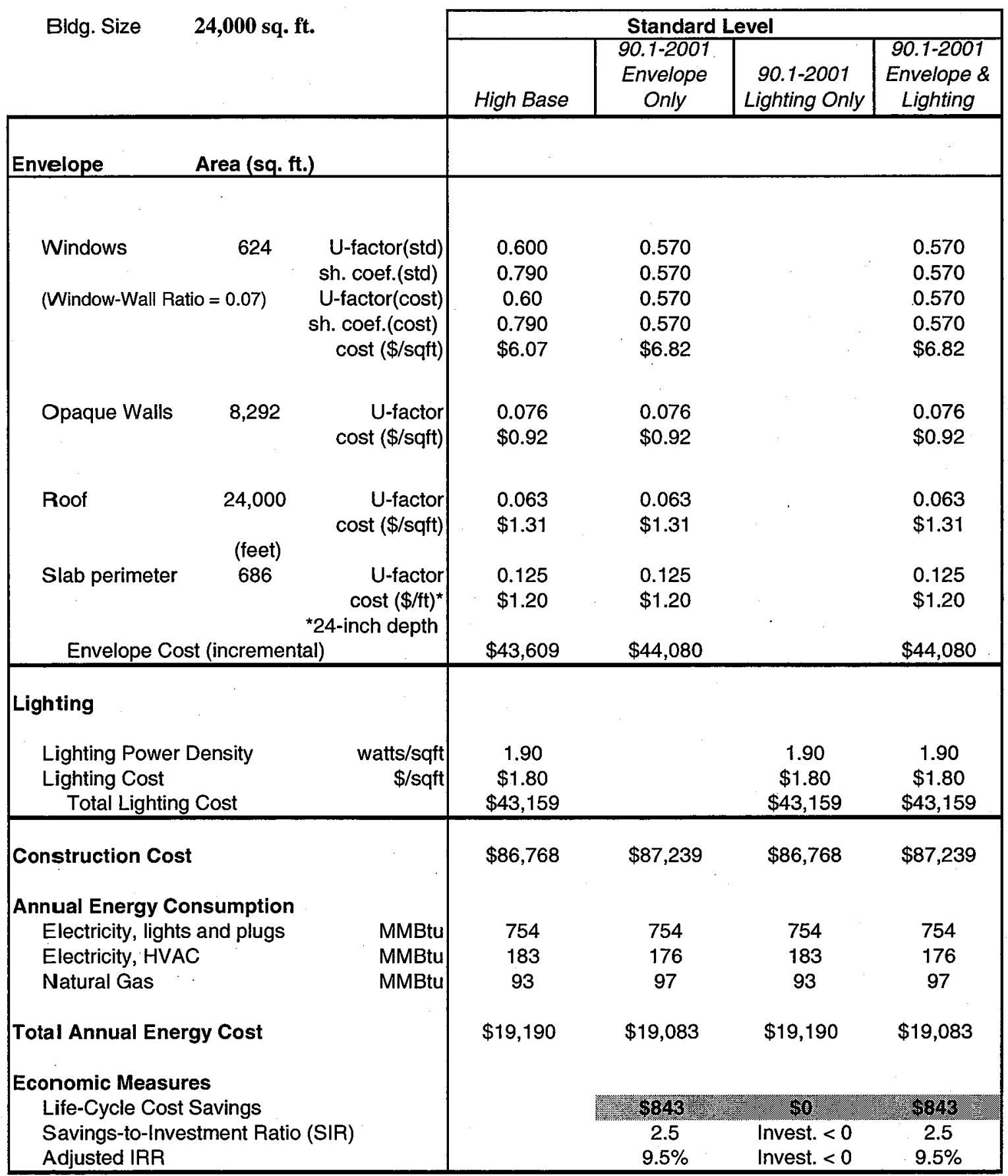

Notes:

1 Slab insulation is assumed in all cases, although not required in 90.1-2001. See text.

2 No economizer used

32004 electricity price $=6.7 \mathrm{cents} / \mathrm{kWh} \quad 2004$ gas price $=\$ 7.98 \mathrm{MMBtu}$

4 Years for Analysis $=40 \quad$ Discount Rate $=\mathbf{7 . 0} \%$

Life-cycle cost savings includes replacement costs and residual values 


\section{Education (elementary)}

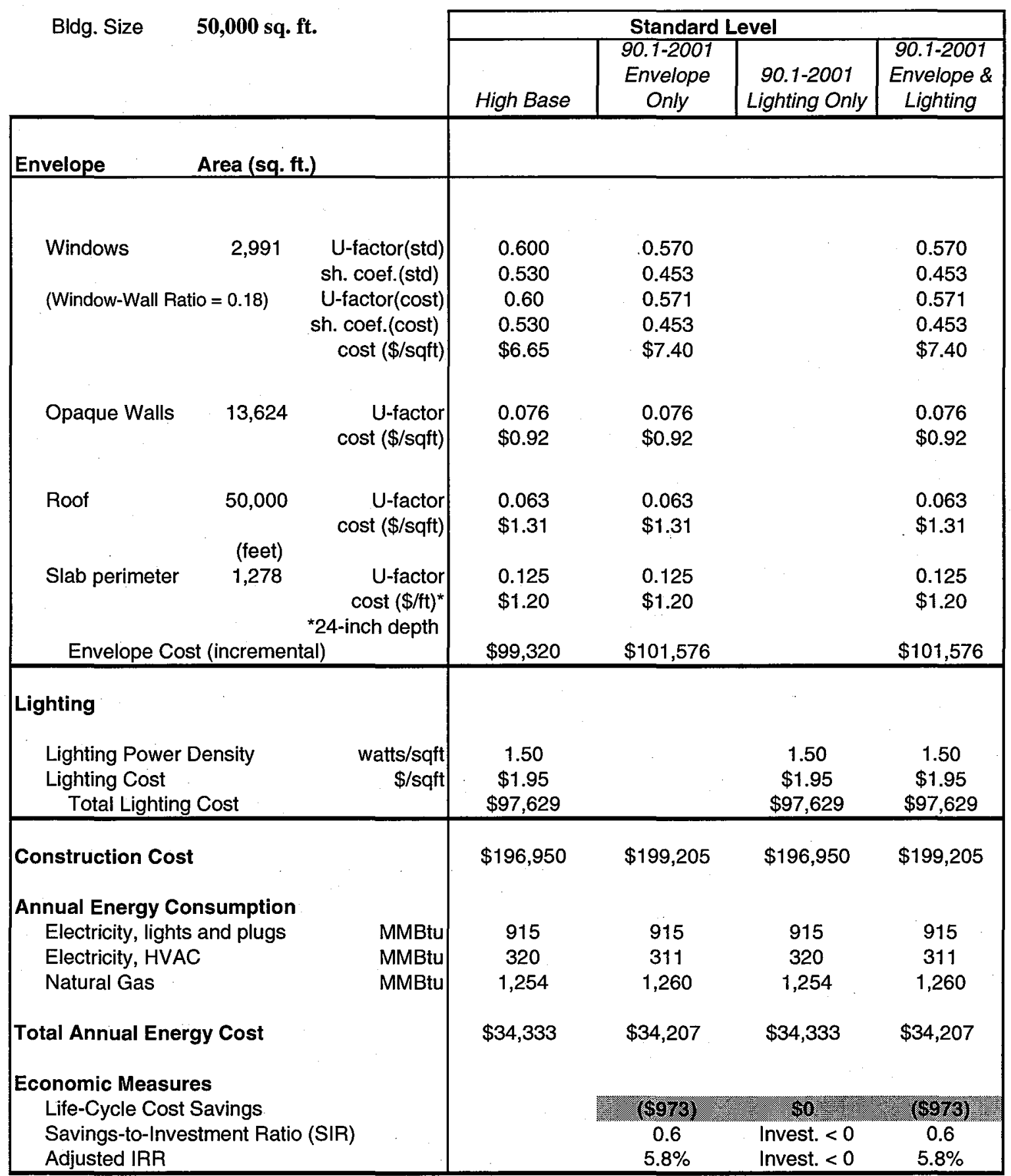

Notes:

1 Slab insulation is assumed in all cases, although not required in 90.1-2001. See text.

2 Economizer used

32004 electricity price $=6.7$ cents $/ \mathrm{kWh} \quad 2004$ gas price $=\$ 7.98 / \mathrm{MMBtu}$

4 Years for Analysis $=\mathbf{4 0} \quad$ Discount Rate $=\mathbf{7 . 0 \%}$

Life-cycle cost savings includes replacement costs and residual values 